\title{
Residence times of shallow groundwater in West Africa: implications for hydrogeology and resilience to future changes in climate
}

\begin{tabular}{|r|l|}
\hline Journal: & Hydrogeology Journal \\
\hline Manuscript ID: & HJ-2012-2262.R3 \\
\hline Category: & Report \\
\hline Date Submitted by the Author: & n/a \\
\hline Complete List of Authors: & $\begin{array}{l}\text { Lapworth, Dan; British Geological Survey, } \\
\text { MacDonanld, Alan; British Geological Survey, } \\
\text { Tijani, Moshood; University of Ibadan, Geology Department } \\
\text { Darling, George; British Geological Survey, } \\
\text { Gooddy, Daren; British Geological Survey, } \\
\text { Bonsor, Helen; British Geological Survey, } \\
\text { Araguás, Luis; IAEA, }\end{array}$ \\
\hline Keywords: & $\begin{array}{l}\text { groundwater recharge/water budget, groundwater age, climate variability, } \\
\text { environmental tracers, Africa }\end{array}$ \\
\hline \multicolumn{2}{|c}{} \\
\hline
\end{tabular}


1 Residence times of shallow groundwater in West Africa: implications for

2 hydrogeology and resilience to future changes in climate

3 Lapworth D.J ${ }^{\mathrm{a} *}$, MacDonald A.M ${ }^{\mathrm{b}}$, Tijani M.N ${ }^{\mathrm{c}}$, Darling W.G ${ }^{\mathrm{a}}$, Gooddy D.C ${ }^{\mathrm{a}}$, Bonsor H.C ${ }^{\mathrm{b}}$,

4 Araguás- Araguás L.J ${ }^{d}$

5

$6 \quad{ }^{a}$ British Geological Survey, Wallingford, OX10 8BB, UK

$7 \quad{ }^{\mathrm{b}}$ British Geological Survey, Edinburgh, EH9 3LA, UK

$8{ }^{\mathrm{C}}$ University of Ibadan, Department of Geology, Nigeria

$9 \quad{ }^{d}$ International Atomic Energy Agency, Vienna

$10 \quad{ }^{*}$ Corresponding author

11 e-mail: djla@bgs.ac.uk

12 Tel: $+44(0) 1491692327$

Fax: $+44(0) 1491692345$

Keywords: groundwater recharge, groundwater age, climate variability, environmental tracers, Africa

Abstract

17 Although shallow groundwater $(<50 \mathrm{mbgl})$ sustains the vast majority of improved drinking water supplies in rural Africa, there is little information on how resilient this resource may be to future changes in climate. This study presents results of a groundwater survey using stable isotopes, CFCs, $\mathrm{SF}_{6}$, and ${ }^{3} \mathrm{H}$ across different climatic zones (annual rainfall 400-2000 mm/y) in West Africa. The purpose was to quantify the residence times of shallow groundwaters in sedimentary and basement aquifers, and investigate the relationship between groundwater resources and climate. Stable-isotope results indicate that most shallow groundwaters sampled are recharged rapidly following rainfall, showing little evidence of evaporation prior to recharge. Chloride mass balance results indicate that within the arid areas ( $<400 \mathrm{~mm}$ annual rainfall) there is recharge of up to $20 \mathrm{~mm} / \mathrm{y}$. Age tracers 
MRTs in the different climate zones. Similar MRTs measured in both the sedimentary and basement aquifers suggest similar hydraulic diffusivity and significant groundwater storage within the shallow basement. This suggests there is considerable resilience to short term inter-annual variation in rainfall and recharge, and rural groundwater resources are likely to sustain diffuse, low volume abstraction.

1. Introduction

In Africa's rural communities approximately 500 million people rely on water resources found in close boreholes (<50 m deep) accessing shallow groundwater is the main way people get access to improved safe drinking water (Foster et al. 2000; JMP 2008; MacDonald and Calow 2009). With growing evidence that improved access to water has major health and economic benefits (Grey and Sadoff 2007; Carter and Bevan 2008; Hunter et al. 2010) there is increasing emphasis on developing groundwater and extending access to the estimated 300 million who are reliant on unimproved and unreliable water sources (JMP 2008; MacDonald and Calow 2009; Bonsor et al. 2011). Recent quantitative groundwater mapping has indicated the existence of significant groundwater storage across much of Africa and hydrogeological conditions that enable boreholes to be successfully drilled and equipped with hand pumps (MacDonald et al 2012) However, there is currently little information on the future availability of shallow groundwater under conditions of increased inter-annual climate variability and rapidly growing populations (Vörösmarty et al. 2000; MacDonald et al. 2009; Bonsor et al. 2011). Although highly uncertain, simulated changes in diffuse groundwater recharge suggest that average recharge in the central Sahel region may increase by the 2050s while in the western coastal areas of West Africa and southern Africa, and coastal areas of North Africa it may decrease significantly (Döll and Flörke 2005). Africa has high rainfall variability, with highest variability occurring in the wettest months (McMahon et al. 2007, Taylor et al., 2009). Compared to river discharge, there are few quantitative studies investigating the relationship between climate and shallow groundwater resources in Africa, and the relationship remains poorly defined (Taylor et al. 2009; MacDonald et al. 54 2009). 
Ideally, a thorough quantitative understanding of aquifer properties and recharge mechanisms under

a variety of climate, land use and geological environments is required to confidently assess current groundwater availability, and forecast future availability under different scenarios. However, such data do not exist for most of Africa (Adelana and MacDonald 2008; Taylor et al. 2009; Baisch 2010) so a different approach is required to investigate the natural resilience of shallow groundwater to changes 61 in climate.

Shallow aquifers containing young waters, a decade or two old, are most susceptible to inter-annual climate variability. Aquifers containing older water with ages in excess of a hundred years are unlikely to be receiving significant modern recharge and although not directly susceptible to climate variability, will be susceptible to groundwater depletion ('mining'). Aquifers with groundwater ages between these two types are likely to be most resilient to high inter-annual rainfall variability.

Measuring groundwater residence times is an effective way of obtaining information about recharge and storage within a hydrogeological system (Cook and Böhlke 2000).Over recent decades environmental tracers have proved to be important tools with a large variety of uses including the quantification of groundwater residence times and mode of recharge (Cook and Herczeg 1999). While these environmental tracer methods have been widely used, and have become important tools for groundwater investigations in parts of Europe, North America and Australia (e.g.Oster et al. 1996; Busenburg and Plummer 1999; Cook et al. 2005; Gooddy et al. 2006) to date there are very few examples of their use within an African context (e.g. Rueedi et al. 2005; Stadler et al. 2010).

The purpose of this work is to help develop the understanding of the hydrogeological processes and assess the resilience of these important resources to short term inter-annual variabililty in the contrasting climates we find in West Africa today. This study represents a first step towards quantifying the mean residence times (MRT) of groundwater pumped from unstressed shallow rural groundwater water supplies in West Africa, by comparing residence times across regions with contrasting rainfall, while controlling for other important factors such as geology, unsaturated zone thickness, rates of abstraction, borehole construction and surface water interaction. In each study 
volume abstraction relative to recharge) in both hard-rock and sedimentary terrains. As part of this study the following environmental tracers were used: stable isotopes, chlorofluorocarbons (CFC-11, CFC-12), sulphur hexafluoride $\left(\mathrm{SF}_{6}\right)$ and tritium $\left({ }^{3} \mathrm{H}\right)$.

\section{Study areas}

The four study areas (Fig.1) were chosen on the basis of annual average rainfall, with distinct climates for each study area, as well as the need to have suitable high-and low-yielding (i.e. sedimentary and basement) aquifers within close proximity. The names given to the four study areas refer to large settlements in each area. Table 1 details the climate zone, rainfall, population and land use characteristics of the four study areas. These data were collected using well established survey methods (Coulter and Calow 2011) within each of the communities where the sampling was carried out.

\subsection{Climate}

The climate within this area of West Africa is controlled by the migration of the Inter-Tropical Convergence Zone (ITCZ) and the Inter-Tropical Front (ITF) which separates the maritime monsoonal air of the Gulf of Guinea from that of the Sahara in northern Africa (Frappart et al. 2009, Lélé and Lamb 2010). The Sahelian rainfall is thought to be almost exclusively dependent on the location and structure of the ITF and is characterized by a unimodal regime that is controlled by the West African Monsoon (WAM, Nicholson 1981). Since the 1960s the Sahel has experienced a multi-decadal drought, with especially dry years in the early 1970 s and 1980 s (Taylor et al. 2002). Over this period there has been a shortening of the rainy season, and an overall increase in the intensity of rainfall events. However, future scenarios regarding changes in precipitation in West Africa for 2050 and beyond are highly uncertain (Parry et al. 2007).

2.2. Geology and hydrogeology

2.2.1. Basement rocks 
117 The basement aquifers targeted in the three Nigerian study areas lie within the Benin-Nigeria Shield

118 (e.g. Grant 1968; Ajibade and Wright 1989). The basement is a patchwork of Neoproterozoic and older Precambrian rocks comprised of migmatitic gneisses with infolds of low- to medium-grade schist belts dominated by clastic metasediments, variably deformed Neoproterozoic granitic intrusions (PanAfrican Older Granites), and smaller and less common meta-basic and meta-ultrabasic intrusions.

Aquifers in these basement rocks have typical yields off $0.1-1 \mathrm{~L} / \mathrm{s}$, with some evidence that the metasediments have slightly higher yields (Hazell et al. 1992; Houston 1992). Groundwater is found mainly within the weathered zone at depths shallower than $40 \mathrm{~m}$ below surface (Wright 1992). The basement is most permeable at the base of the weathered zone where the rock is fractured but still coherent; the more weathered material above this has lower permeability, but greater storage (Chilton and Foster 1995). In this study boreholes were sampled within the schist belts and migmatitic gneisses; sites in or close to the Older Granite intrusions were avoided due to potential sources of $\mathrm{SF}_{6}$ from naturally occurring mineralization (Harnisch et al. 2000).

\subsubsection{Sedimentary rocks}

The sedimentary rocks in each case are from Mesozoic and younger sediments. They are typically several tens to hundreds of metres thick. The sedimentary rocks of the Abeokuta study area (Fig.1) were sampled from the Abeokuta Formation. Boreholes within the basin can support higher yields 
146 (Nupe Group) within the Bida basin forms the sedimentary aquifer for the Minna study area. Highly 147 variable yields of $1-5 \mathrm{~L} / \mathrm{s}$ have been reported within this formation (Okafor 1991). The sedimentary 148 aquifer in the Gusau area is the Upper Cretaceous cover of the Gundumi Formation is located in the Sokoto basin and comprising grits, clays and pebble beds (Adelana et al. 2008). This aquifer can support high yielding boreholes (10-30 L/s) and has a high porosity.

151

In Mali, the sedimentary aquifer is the Continental Terminal Formation (CT) of Eocene age. The shallow CT aquifer comprises mostly unconfined unconsolidated sediments, sealed at depth by clay. Boreholes typically can support a yield of $5-10 \mathrm{~L} \cdot \mathrm{s}^{-1}$, and storage can be high due to the high porosity (MacDonald et al. 2012). The area sampled in this case study is a closed drainage basin and uncoupled from the seasonal flooding of the nearby Niger basin, but may still be locally coupled to springs emerging from the Bandigara plateau, as well as ephemeral rivers and ponds. Parts of the CT basin have experienced a significant rise in the groundwater table in recent years, equivalent to an increase in groundwater reserves of $10 \%$ between 1960s-1990s, which has been linked to decadal scale changes in land use and recharge conditions due to irrigation (Leduc et al. 2001; Favreau et al. 2002).

162

\section{Methodology}

164

\subsection{Environmental Tracers}

166 have been used in this study: tritium and trace gases.

3.1.1. Stable Isotopes

173

Stable $\mathrm{O}$ and $\mathrm{H}$ isotopes are tracers of physical processes that water molecules undergo between evaporation from the ocean and arrival in the aquifer via recharge of rainfall Clark and Fritz 1997). 
They are typically used in semi-arid hydrogeological studies to indicate the degree to which waters may have been modified prior to recharge (e.g. Favreau et al. 2002) or the existence of pre-Holocene waters (Ó Dochartaigh et al. 2010). They have been successfully used within the arid and semi-arid environments of West Africa to assess the modes of both modern and palaeo groundwater recharge (Acheampong and Hess 2000; Edmunds et al. 2004; Goni 2006; Diop and Tijani 2008).

\subsubsection{Tritium}

The use of tritium in hydrogeological investigations relies on the large input of tritium $\left({ }^{3} \mathrm{H}\right.$, half-life 12.3 yr) to the atmosphere during the thermonuclear testing of the mid-1960s. Almost four half-lives have elapsed since then, resulting in present-day rainfall values near the pre-testing baseline.

Nevertheless, ${ }^{3} \mathrm{H}$ still has a role to play in groundwater studies by supplimenting evidence from other age indicators (Knowles et al. 2010). The rainfall ${ }^{3} \mathrm{H}$ record for West Africa is not particularly wellconstrained, but data from the global network of isotopes in precipitation (GNIP 2011) has been combined with measurements by Leduc et al. (1996) and Onuga and Aboh (2009) to arrive at the curve shown in Fig. $\mathrm{S} 1$ in the electronic supplementary material (ESM).

\subsubsection{Trace gas age indicators}

The use of $\mathrm{CFCs}$ and $\mathrm{SF}_{6}$ as groundwater age tracers relies on the rise in their atmospheric concentrations over the last 50 years together with certain assumptions about atmospheric mixing and recharge solubility (Plummer and Busenberg 1999). These gases are known to be well-mixed in the atmosphere so the curves are considered to be applicable to the study area. The use of several trace gases is recommended as under certain conditions individual tracers may have limitations (Darling et al. 2012). In particular, the CFCs may be affected by pollution, and/or degradation under anaerobic conditions (Plummer and Busenberg 1999), and there are also issues with the use of $\mathrm{SF}_{6}$ due to terrigenic production (Koh et al. 2007).

Interpreting trace gas indicators relies on consideration of mean recharge temperature, altitude and incorporation of excess air. An average annual air temperature of $28^{\circ} \mathrm{C}$ was used for this study to 
represent recharge temperatures. Fig. S2 in the ESM shows the translation of the atmospheric curves into groundwater concentrations at this temperature. Altitude does not exceed $500 \mathrm{~m}$ in any of the areas so correction for altitude is considered unnecessary given other sources of error and uncertainty. The phenomenon of 'excess air' incorporated during recharge has only a small effect on the $\mathrm{CFCs}$ but requires correction for $\mathrm{SF}_{6}$ measurement. While no 'excess air' measurements were made during the study, raw $\mathrm{SF}_{6}$ measurements have been corrected using a value of $3 \mathrm{ccSTP} / \mathrm{L}$ for intergranular sediments and $5 \mathrm{ccSTP} / \mathrm{L}$ for fractured formations, based on the data of Wilson and McNeill (1997).

As the four atmospheric environmental tracers used in this study (CFC-11, CFC-12, SF 6 and ${ }^{3} \mathrm{H}$ ) have differing temporal patterns to their input functions, plots of one tracer against another can be useful in distinguishing the hypothetical groundwater flow processes that may affect the samples, in addition to identifying anthropogenic contamination. Lumped parameter models (LPM) typically used to describe some of the variation seen in groundwater mixtures include piston flow (PFM), exponential mixing (EMM) and binary mixing (BMM) (Zuber 1986; Cook and Böhlke 2000). Comparison of multiple environmental tracer data can indicate if simple models like these are applicable, and mean groundwater residence times or mixing ratios calculated accordingly.

3.2. Sample site selection

All sites sampled were functioning boreholes in use by the community immediately prior to sampling. Most of the boreholes were hand-pumped, though in the case of the Abeokuta study area there were very few functioning hand pumps so boreholes fitted with low-yielding submersible pumps were sampled instead. Two sites with larger volume abstractions for irrigation were also sampled in the Gusau area. Only sites with head-works and sanitary seals in good repair were sampled. Apparently suitable sites were avoided if there was a large ponded area, or a natural surface water body, close to the borehole which could potentially lead to additional localised recharge. A total of 57 sites were 
sampled across zones of contrasting annual average rainfall, with approximately equal numbers of samples taken from each study area and geology (see Table 2). For each of the four study sites an area of approximately $1000 \mathrm{~km}^{2}$ was covered. This was required in order to sample a sufficient number of hand pumps in good repair, collect samples from across each region and geology, and also because of the dispersed nature of settlements.

Field measurements of dissolved oxygen $\left(\mathrm{DO}_{2}\right), \mathrm{pH}$, specific electrical conductance (SEC) and temperature were made at the wellhead using a flow-through cell. Sampling was carried out only after stable instrument readings were obtained for the field parameters. Samples for chloride determination were filtered $(<0.45 \mu \mathrm{m})$ in the field, stored in nalgene ${ }^{\mathrm{TM}}$ bottles and refrigerated prior to analysis by liquid chromatography.

Samples for stable isotope analysis were collected unfiltered. Analysis was carried out using standard preparation techniques followed by isotope ratio measurement on a VG-Micromass Optima mass spectrometer. Data considered in this paper are expressed in \%o with respect to Vienna Standard Mean Ocean Water (VSMOW). Tritium samples were collected in 1-L HDPE bottles. Analysis was carried out by decay counting following pre-concentration by electrolytic enrichment.

CFC and $\mathrm{SF}_{6}$ samples were collected unfiltered and without atmospheric contact in sealed containers by the displacement method of Oster (1994). This method ensures that the sample is protected from possible atmospheric contamination by a protective jacket of the same water. CFCs and $\mathrm{SF}_{6}$ were measured by gas chromatography with an electron capture detector after pre-concentration by cryogenic methods, based on the methods of Busenberg and Plummer (1999).

Measurement precision was within $\pm 0.1 \%$ for $\delta^{18} \mathrm{O}$ and $\pm 1 \%$ for $\delta^{2} \mathrm{H}$, as indicated for ${ }^{3} \mathrm{H}$, and $\pm 5 \%$ for the CFCs and $10 \%$ for $\mathrm{SF}_{6}$, with detection limits of $0.01 \mathrm{pmol} / \mathrm{L}$ (CFC-12), $0.05 \mathrm{pmol} / \mathrm{L}$ (CFC-11) and 
BGS laboratories in the UK. Tritium was analysed by the International Atomic Energy Agency (IAEA) in Vienna.

\section{Results}

Summary statistics for groundwater residence time tracers (CFC-11,CFC-12, $\mathrm{SF}_{6}$ and ${ }^{3} \mathrm{H}$ ), groundwater stable isotopes $\left(\delta^{18} \mathrm{O}\right.$ and $\left.\delta^{2} \mathrm{H}\right)$, groundwater mean residence times (MRT), chloride, as well as field observations of $\mathrm{DO}_{2}$ are presented in Table 2. A complete set of results is available in Table S1, in the accompanying ESM.

\subsection{Stable isotopes}

Summary stable isotope results $\left(\delta^{18} \mathrm{O}\right.$ and $\left.\delta^{2} \mathrm{H}\right)$ are provided in Table 2. When plotted on a $\delta$-diagram (Fig. 2) they show a good conformance with the GMWL $\left(\delta^{2} \mathrm{H}=8 \delta^{18} \mathrm{O}+10\right)$, indicating that infiltration occurred either areally during rainfall events or shortly afterwards via focused recharge from minor surface ponding. A robust regression line calculated using the stable isotope data is given as $\delta^{2} \mathrm{H}=8.03 \delta^{18} \mathrm{O}+10.04$, with an $\mathrm{r}^{2}$ of 0.89 . It is noteworthy that overall there is no systematic bias towards enriched or depleted values relative to the GMWL. Any recharge from longer-residence ponds or lakes would be likely to exhibit signs of evaporative fractionation, particularly in the semi-arid areas. The only sites showing evidence for this were M1 and M6 from the CT aquifer in Mali. M1 was in close proximity to a large seasonal pond, but the source of recharge to M6 remains unclear. Analysis of variance showed that there are significant differences in stable isotope signatures between different study areas $(p<0.001)$. The trend in decreasing $\delta^{18} \mathrm{O}(-2$ to $-5.5 \%)$ and $\delta^{2} \mathrm{H}(-10$ to $37 \%$ ) with decreasing annual rainfall (Fig. 2) is consistent with the largely convective origin of the rainfall as it tracks north from the Gulf of Guinea inland during the wet season. No significant $(p>0.05)$ difference was found for isotope values in the different geology within each study area.

4.2. Tritium

Tritium values range from approximately zero to $7.3 \mathrm{TU}$ (Table 2), suggesting a range of ages, but these are difficult to interpret quantitatively partly owing to the lack of detailed knowledge about inputs of ${ }^{3} \mathrm{H}$ in rainfall over time. Statistical analysis (Fig. 3a) shows certain differences between the four 
295

296

297

299

300

301

302

303

areas and the two lithologies (basement and sedimentary). A general lowering in activities towards the coast may be due to the dilution effect on rainfall of low-tritium water vapour from the ocean (Gat 1980), while in the basement areas there could be terrigenic production of ${ }^{3} \mathrm{H}$ from the presence of $U$, Th, Li and B (Andrews and Kay 1982).

\subsection{CFCs and $\mathrm{SF}_{6}$}

Results for groundwater residence time tracers are shown in Table 2, divided by study area and aquifer type. It is clear that some of the measured CFC and $\mathrm{SF}_{6}$ concentrations considerably exceed the maximum equilibrium values for a recharge temperature of $28^{\circ} \mathrm{C}(\mathrm{CFC}-12=1.4 \mathrm{pmol} / \mathrm{L}, \mathrm{CFC}-11=$ $\left.2.4 \mathrm{pmol} / \mathrm{L}, \mathrm{SF}_{6}=1.5 \mathrm{fmol} / \mathrm{L}\right)$, suggesting that concentrations in some waters have been affected by augmentation from anthropogenic or terrigenic sources. It is also apparent from the $\mathrm{DO}_{2}$ data (Table 2) that there is potential for CFC degradation due to the anaerobic groundwater conditions across the study areas in Nigeria.

Mean residence times for groundwaters were calculated using an exponential mixing model, results were found to fall in the EMM-BMM envelope, and the piston flow model was the least suitable model. A statistical summary of the estimated MRT results is presented in Figure 3b. In most cases $\mathrm{SF}_{6}$ data were used as the input data, however for the few sites where this exceeded modern recharge values and waters were aerobic (>1 mg/L DO $)$ and there was no clear evidence of CFC-12 degradation, CFC-12 values were used instead. The results from a Kruskal-Wallis test (Hollander and Wolfe 1973) comparing MRT results between each climate zone show the mean ranks for the four zones are not significantly different $(p>0.1)$.

\section{Discussion}

\subsection{Recharge processes}

Although potential evaporation in arid and semi-arid regions exceeds rainfall, often by a factor of three or four times, other studies in West Africa have shown that this does not mean that diffuse areal 
recharge is insignificant (Scanlon et al. 2006). For example, in northeast Nigeria recharge of up to 30 $\mathrm{mm} / \mathrm{yr}$ has been reported based on the use of a range of techniques including chloride mass balance (CMB), water balance calculations, and observations of water level fluctuations (Carter 1994; Carter and Alkali 1996; Edmunds et al. 1999).

While no unsaturated zone CMB studies were undertaken during the present study, a simple estimation of potential recharge $R_{\mathrm{D}}$ was calculated for the Bandigara study area using the formula $R_{\mathrm{D}}=P C_{\mathrm{p}} / C_{\mathrm{s}}$ where $P$ is the average regional annual rainfall $(\mathrm{mm}), C_{\mathrm{p}}$ is the spatially averaged rainfall $\mathrm{Cl}(\mathrm{mg} / \mathrm{L})$ and $C_{\mathrm{s}}$ is the groundwater concentration $\mathrm{Cl}(\mathrm{mg} / \mathrm{L})$. Rainfall $\mathrm{Cl}$ concentrations used were $0.26 \mathrm{mg} / \mathrm{L} \mathrm{Cl}$, (Galy-Lacaux et al. 2009). This CMB approach gives an average recharge value of 20 $\mathrm{mm} \cdot \mathrm{yr}^{-1}$ and a large range of $4-43 \mathrm{~mm} / \mathrm{yr}$, equivalent to between $1.2-12 \%$ annual rainfall across this study area. Overall these values compare well with other field based studies in semi-arid areas (Scanlon et al. 2006) as well as modeled estimates (Döll et al. 2003). While this model is useful in semi-arid regions many assumptions behind it break down in wetter regions (Scanlon et al. 2002; Healy 2010) leading to unreliable results and therefore no attempt was made to use this model to estimate recharge in the other study areas.

The generally unfractionated stable isotope values found in this study suggest a rapid recharge mechanism following rainfall, and the predominance of diffuse recharge across most parts of the areas studied. However, this may also include recharge from transient surface ponding that perhaps lasts only a few days. The two observed departures from the GMWL are likely to be due to the effect of focused recharge from longer lasting seasonal ponds and rivers (which were observed in Mali and northern Nigeria) following episodic rainfall events. These findings corroborate other studies which have shown that the shallow groundwaters in West Africa are coupled to recent climate and recharge processes (Edmunds et al. 1999; Acheampong and Hess 2000; Rueedi et al. 2005; Onugba and Aboh 2009) and are also consistent with other studies in semi-arid parts of sub-Saharan Africa (e.g. Favreau 2000; Bromley et al. 2002; Favreau et al. 2002).

The existence of diffuse areal recharge does not in itself imply a particular route to the water table. CMB studies in semi-arid areas indicate delays of up to $10^{1}-10^{2} \mathrm{yr}$ in transit through the unsaturated 
zone, yet the existence of anthropogenic tracers like the CFCs in the underlying aquifers shows that more direct recharge also occurs, promoted by fracturing, root development or other factors (Edmunds et al. 1999; Stadler et al. 2010). In this study the unsaturated zone was relatively thin (8-20 m) so the lag due to tracer diffusion and transport through the unsaturated zone would be small $(<1-4$ years) relative to the overall MRT (Cook and Solomon, 2003). In addition, groundwater transport through the unsaturated zone, particularly episodic recharge, would be rapid resulting in only a small travel time in the unsaturated zone (Stadtler et al. 2010).

\subsection{Groundwater residence time and mixing}

Using multiple residence time tracers has two main benefits: instances of contamination or degradation in one tracer can be offset by others unaffected, and a better understanding of flow processes is potentially achievable (e.g. Darling et al., 2012). Reference has already been made to instances of contamination, such as the production of terrigenic $\mathrm{SF}_{6}$ in basement rocks and localised CFC contamination (see section 4.4). Results for such samples (identifiable by their over-modern concentrations) have been filtered out of the dataset to be used for dating purposes. The remaining results can be interpreted by co-plotting the tracers (Fig. 4) onto a framework of basic lumped parameter models (LPMs).

A plot of CFC-11 versus CFC-12 shows samples cluster on or around the piston flow (PFM) and binary mixing (BMM) lines (Fig. 4a). The spread of samples beyond the LPM lines suggest that processes apart from residence time are affecting CFC concentrations. One likely process is the degradation of CFCs under low-oxygen conditions (Oster et al. 1996). Samples with $<0.5 \mathrm{mg} \cdot \mathrm{L}^{-1} \mathrm{DO}_{2}$ are indicated and tend towards low concentrations of both CFCs. Though it is known that CFC-11 is more rapidly affected by reduction than CFC-12, Fig. 4a does not show a bias towards this, suggesting that reduction has been going on for long enough to affect both CFCs. Unaffected samples show a slight bias towards CFC-12, perhaps indicating a minor source of contamination. Owing to the proximity of the PFM and BMM lines it is not possible to assign samples to a particular flow regime. Most samples unaffected by reduction have a piston-flow mean residence time (MRT) 
$>30 \mathrm{yr}$ or have $<50 \%$ modern water in them depending on the chosen hydrogeological model. There appears to be no gross difference between the basement and sedimentary results.

Fig. $4 \mathrm{~b}$ shows a plot of $\mathrm{CFC}-12$ versus $\mathrm{SF}_{6}$. The simplest interpretation of this plot is that samples to the left of the LPM envelope have been affected by one of two processes: CFC-12 reduction for low$\mathrm{DO}_{2}$ samples, and terrigenic production of $\mathrm{SF}_{6}$ where $\mathrm{DO}_{2}$ exceeds $0.5 \mathrm{mg} \cdot \mathrm{L}^{-1}$. On the assumption that one or the other process is operating, most samples have an MRT $>15 \mathrm{yr}$ or have $<40 \%$ modern water. The possibility of some samples suffering from both processes cannot be excluded but the number of significantly-affected samples is small and would in most cases not affect the above estimates. As with Fig. 4a it is difficult to discern any difference between basement and sedimentary groundwaters.

Tritium is not affected by reduction or (except in very specific cases) by contamination. Therefore plots involving ${ }^{3} \mathrm{H}$ have an advantage in that regard. The limitations of the ${ }^{3} \mathrm{H}$ input for West Africa have been discussed in section 3.1.2. The plot of $\mathrm{CFC}-12$ versus ${ }^{3} \mathrm{H}$ (Fig. 4c) shows the expected bias of low- $\mathrm{DO}_{2}$ samples towards low CFC-12 concentrations. Some of these reduced samples project onto the PFM line only, a conclusion that could not be drawn from the plots in $4 a$ and $b$. Samples below the BMM line support the indications of Fig. 4a that some samples have minor CFC contamination. Most samples appear to have MRTs $>25$ yr or $<70 \%$ modern water.

A plot of $\mathrm{SF}_{6}$ versus ${ }^{3} \mathrm{H}$ (Fig. 4d) shows the lowest scatter of data points of all the residence time plots, suggesting by reference to Figs $4 a-c$ not only that low- $\mathrm{DO}_{2}$ conditions have affected the CFCs, but that CFCs in more oxygenated waters may also have been affected by reduction: mixing within the borehole between anaerobic and higher- $\mathrm{DO}_{2}$ waters could have this effect. Most samples in Fig. 4d fall within the BMM-EMM envelope, and it therefore seems reasonable to use the EMM to calculate MRTs. Highest $\mathrm{SF}_{6}$ concentrations below the BMM belong to two basement aquifer samples and suggest the existence of terrigenic production. In simple terms the plot indicates most samples have $<60 \%$ modern water, a few samples have piston flow ages of $20-25 \mathrm{yr}$, and that some samples are intermediate in origin between EMM and BMM flow models. 
5.3. Implications for the hydrogeology of shallow aquifers

415

Fig. 5 summarises the estimated MRT results as cumulative probability plots for the basement and sedimentary aquifers. The similarity in the distribution of MRTs for the sedimentary and crystalline basement implies that the rate of through-flow of shallow groundwater is comparable in the two aquifer types (Table 2). This would suggest similar hydraulic diffusivity (T/S), where $T$ is transmissivity and $S$ is storage, and shallow circulation within the top $20-50 \mathrm{~m}$ of the aquifers. The consistently large range of MRTs in the basement aquifers also indicates that there is sufficient storage within these aquifers to allow a range of differently aged groundwaters to be stored and mixed. These results would be consistent with the slightly higher effective porosity of approximately $1-10 \%$ in the weathered basement aquifer suggested by engineering geology studies (Taylor and Eggleton 2001) than the $<1 \%$ generally assumed by hydrogeologists (Wright 1992). The higher effective porosity of 25-35\% (Adelana et al. 2008; Nwankwo et al. 2009) within the sandstone aquifers is offset by the higher transmissivity. Fig. 6 shows a simplified conceptual diagram of groundwater recharge processes for (a) basement and (b) sedimentary aquifers in arid zones summarising why similar MRTs are found in shallow groundwaters in both types of aquifers.

The similarity of MRTs across the different climate zones is perhaps a more surprising result. In the increasingly arid northern climates it might be expected that residence times would increase, since modeled groundwater recharge reduces (Döll and Fiedler 2008). These preliminary findings suggest that there is no simple link between MRT in shallow groundwaters and current long term average rainfall. Due to the limited current understanding of recharge and hydrogeological processes in the basement, reasons for the observed similar range in MRT for groundwater from 20-50 m boreholes across zones of highly contrasting annual rainfall remain speculative.

Possible explanations for the similar MRT in basement aquifers in both arid and humid zones are presented as a conceptual diagram in Fig. 7. Effective recharge in humid areas (Fig. 7a) is physically limited by lateral flow (when saturated soil flux is exceeded) along shallow permeable layers and 442 surface runoff irrespective of changes in potential recharge. Low permeability layers in the saprolite, as a result of weathering processes, are common and an obvious barrier to groundwater recharge 
444 and facilitate rapid lateral flow irrespective of current climatic conditions (Chilton and Smith-Carington

445 1984; Jones 1985; Chilton and Foster 1999). Generally shallower regional water tables in humid

446 areas (Fig. 7a) lead to a greater saturated thickness of weathered basement and therefore greater

447 groundwater storage than in more arid areas (Fig. 7b) with deeper groundwater levels. Consequently,

448 greater recharge in more humid areas would be offset by the higher storage to give MRTs similar to

449 arid areas; a similar ratio between effective recharge and storage across the zones of contrasting

450 rainfall and would help to explain the similar MRT. In this study the shallowest groundwater levels

451 were found in the most humid areas (Table 1), although overall there was considerable overlap

452 across the study areas.

453

454

5.4. Resilience of improved rural water resources to climate variability

455

456

Shallow groundwater resources currently play an important role in providing sustainable drinking water sources across Africa, and will continue to do so in the future. While there are major uncertainties in climate model predictions there is some consensus that there will be an intensification of past climate variability in the future (Parry et al. 2007). In light of this, unimproved ephemeral sources will continue to be the least resilient to changes in climate variability, while groundwater resources are better able to buffer any inter-annual variability in rainfall and recharge (MacDonald and Calow 2009; Bonsor et al. 2011). In all of the study areas, even in the most arid, the results of this study show that there is strong evidence of modern recharge. The shallow groundwater abstracted from rural hand pumps in both basement and sedimentary aquifers is a composite water with intermediate MRTs, giving an inherent resilience to short term changes in recharge. Overall, no significant difference in MRT was found within these shallow aquifers across a range of climates, from semi-arid zones to humid tropical zones. These factors together provide compelling evidence to support the assertion that any future changes in rainfall and recharge due to changes in climate are unlikely to lead to continent wide failure of improved groundwater supplies (MacDonald et al. 2009; Bonsor et al. 2011; MacDonald et al. 2012).

472 There is a growing body of evidence that more intense periods of rainfall and/or landuse changes could lead to increased episodic recharge, and therefore further increase the security of rural water 
474

475

476

supplies (Taylor and Howard 1996; Favreau et al. 2009). However, future pressures on groundwater resources for irrigation or due to increased population density may lead to much higher abstraction and need to be carefully managed, particularly in hard-rock areas where storage can be highly spatially variable (Foster 2012; MacDonald et al. 2012).

While it is not the main focus of this paper, there are clearly also important water quality implications for shallow groundwater sources from any future changes in rainfall distribution, and/or land use (Bijay-Singh et al. 1995; Kundzewicz et al. 2007). These include the potential for increased microbiological contamination from unsuitable sewerage systems, due the intensification of rainfall and episodic recharge (Howard et al. 2003; Taylor et al. 2009), groundwater pollution from pesticides and nitrate due to shifts towards more intensive crop production (e.g. Favreau et al. 2009) and pollution due to urbanisation/industrialisation (Adelana et al. 2008).

\section{Summary and conclusions}

This study has attempted to apply environmental tracer techniques to better characterise the shallow ( $<50 \mathrm{~m}$ deep) groundwater resources in West Africa. Comparisons were made between basement aquifers and sedimentary aquifers within four study areas of different annual mean rainfall, from a semi-arid zone in central Mali with rainfall of between $350-400 \mathrm{~mm} / \mathrm{yr}$ to the humid tropical zone of southwest Nigeria with between $1800-2000 \mathrm{~mm} / \mathrm{yr}$. The main conclusions from this study are summarised below:

1. Stable isotopes indicate the predominance of rapid infiltration following rainfall even within the most arid zone with annual rainfall of between $350-400 \mathrm{~mm} / \mathrm{yr}$. There is strong evidence of modern recharge from a range of other geochemical tracers $\left(\mathrm{SF}_{6}, \mathrm{CFCs},{ }^{3} \mathrm{H}\right)$.

2. In the most arid study area, recharge estimates using the chloride mass balance approach gave values of $20 \mathrm{~mm} / \mathrm{yr}$, equivalent to $6 \%$ of annual average precipitation.

3. Shallow groundwaters in the top $50 \mathrm{~m}$ of the subsurface have MRTs of 4-70 years (range) and 32-65 years (first and third quartile); median MRT values for each study area were found to be $>30$ years irrespective of average annual rainfall. 
4. Similar MRTs were found in shallow groundwater in sedimentary and basement aquifers, indicating considerable storage within shallow basement and comparable hydraulic diffusivity within the two aquifers.

506

The results presented here support the view that shallow groundwater resources in both basement and sedimentary aquifers across this region have an inherent natural resilience to climate variability and are able to buffer the effects of reduced rainfall and recharge during short-term periods of drought. However, there is a clear coupling between modern rainfall and active recharge across the region so if, as has been predicted, future monsoon rainfall becomes more intense for parts of West Africa, then episodic recharge may increase in the future within more arid regions.

Acknowledgements

This work was funded by the UK Department for International Development. The authors are grateful for the support of the following: field staff from the Nigerian Geological Survey Agency and for logistical support in Nigeria; Vinny Casey and Richard Carter of WaterAid London ; Adama Sanogo and colleagues in WaterAid Mali; and local partners: GAAS (Bandigara), AFRAD (Koro), and ADDA in Mali. The research was carried out under guidance from a steering group headed by Guy Howard (DFID) and Stephen Foster (IAH). David M.J. Macdonald (BGS) is thanked for reviewing the draft manuscript. The authors thank J Barth and A Herczeg for their constructive comments during the review process. BGS authors publish with the permission of the Executive Director of the British

\section{Geological Survey (NERC).}

References

Acheampong SY, Hess JW (2000) Origin of the shallow groundwater system in the southern Voltainan Sedimentary Basin of Ghana: and isotopic approach. J Hydrol 233: 37-53

Adanu E.A (1991) Source and recharge of groundwater in the basement terrain in the Zaria-Kaduna area, Nigeria: applying stable isotopes. J Afr Earth Sci 13: 229-234 
532 research studies in Africa. IAH selected papers on hydrogeology, vol 13, CRC press/Balkema, pp $533 \quad 231-260$

Adelana SMA, MacDonald AM (2008) Groundwater research issues in Africa. In: Adelana SMA, MacDonald AM (eds) Applied research studies in Africa. IAH selected papers on hydrogeology, vol 13, CRC press/Balkema, pp 1-7

Adelana SMA, Olasehinde PI, Bale RB, Vrbka P, Edet AE, Goni IB (2008) An overview of the geology 538 and hydrogeology of Nigeria. In: Adelana SMA, MacDonald AM (eds) Applied research studies in 539 Africa. IAH selected papers on hydrogeology, vol 13, CRC press/Balkema, pp 177-197

540 Ajibade AC, Wright JB (1989) The Togo-Benin-Nigeria shield: evidence of crustal aggregation in the 541 Pan-African belt. Tectonophys 165: 125-129

542 Allen DJ, Brewerton LJ, Coleby LM, Gibbs BR, Lewis MA, Macdonald AM, Wagstaff SJ, Williams AT 543 (1997) The physical properties of major aquifers in England and Wales. British Geological Survey 544 Technical Report WD/97/34, Environment Agency R\&D Publication 8. British Geological Survey 545 Andrews J N, Kay RL F (1982) Natural production of tritium in permeable rocks. Nature 298: 361-363 546 Baisch J (2010) Data shortage in Africa. Desalination 252:107-112

547 Bijay-Singh, Yadvinder-Singh, Sekhon, GS (1995). Fertilizer-N use efficiency and nitrate pollution of 548 groundwater in developing countries. J Contam Hydrol 20: 167-184.

549 Bonsor HC, MacDonald AM, Calow RC (2011) Potential impact of climate change on improved and 550 unimproved water supplies in Africa. RSC Issues in Environ Sci Technol 31: 25-50

551 Busenberg E, Plummer LN (1999) Dating young groundwater with sulfur hexafluoride: Natural and 552 anthropogenic sources of sulfur hexafluoride. Water Resources Res 36(10): 3011-3030

553 Bromley J, Taylor CM, Gash JHC (2002) Discussion-comment on 'long-term rise in a Sahelian water554 table: the continental terminal in South-West Niger by Leduc C, Favreau G, Schroeter P (2001). J 555 Hydrol. 243: 43-54'. J Hydrol 255: 260-262

556 Bromley J, Edmunds WM, Fellman E, Brouwer J, Gaze SR, Sudlow J, Taupin J-D (1997) Estimation 557 of rainfall inputs and direct recharge to the deep unsaturated zone of southern Niger using the 558 chloride profile method. J Hydrol 188-189: 139-154

559 Carter RC (1994) The groundwater hydrology of the Manga grassland, northeast Nigeria: importance 560 to agricultural development strategy for the area. QJ Eng Geol Hydrogeol 27: 573-583 
575

576

577 578

579

580

581

582

Carter RC, Bevan JE (2008) Groundwater development for poverty alleviation in sub-Saharan Africa. In: Adelana SMA, MacDonald AM (eds) Applied groundwater research in Africa. IAH Selected Papers in Hydrogeology 13, Taylor \& Francis, Amsterdam, pp 25-42

Carter RC, Alkali AG (1996) Shallow groundwater in the northeast arid zone of Nigeria, Q J Eng Geol Hydrogeol 29: 341-355

Chilton PJ, Foster SSD (1995) Hydrogeological characterisation and water-supply potential of basement aquifers in tropical Africa. Hydrogeol J 3: 36-49

Chilton PJ, Smith-Carington AK (1984) Characteristics of the weathered basement aquifer in Malawi in relation to rural water supplies. In: Walling DE, Foster SSD, Wurzel P (eds) Challenges in African hydrology and water resources IAHS Publ. no. 144, pp 57-72

Clark ID, Fritz, P (1997) Environmental Isotopes in Hydrogeology. Lewis Publishers, Boca Raton.

Cook PG, Böhlke J-K (1999) Determining timescales for groundwater flow and solute transport. In: Cook P, Herczeg A (eds) Environmental Tracers in Subsurface Hydrology. Kluwer Academic Publishers, Boston, MA, pp 1-30

Cook PG, Solomon DK (1995) Transport of atmospheric trace gases to the water table: Implications for groundwater dating with chlorofluorocarbons and krypton 85. Water Resources Research 31: 263270.

Cook PJ, Herczeg A (1999). Environmental Tracers in Subsurface Hydrology. Kluwer Academic Publishers, Boston, MACoulter L, Calow, RC (2011). Assessing seasonal water access and implications for livelihoods, RiPPLE WELS Toolkit report, RiPPLE-ODI Ethiopia. www.rippleethiopia.orgCraig H (1961) Isotopic variations in meteoric waters. Science 133:1702-1703 Darling WG, Gooddy DC, Riches J, Wallis I (2010) Using environmental tracers to assess the extent of river-groundwater interaction in a quarried area of English Chalk. Appl Geochem 25: 923-932

Darling WG, Gooddy DC, MacDonald AM, Morris BL (2012) The practicalities of using CFCs and SF 6 for groundwater dating and tracing. Appl. Geochem 27: 1688-1697

Diop S, Tijani MN (2006) Assessing the basement aquifers of Eastern Senegal. Hydrogeol J 16: 1349-1369

Döll P, Kaspar F, Lehner B (2003) A global hydrological model for deriving water availability indicators: model tuning and validation. J Hydrol 270: 105-134

Döll P, Fiedler K (2008) Global-scale modelling of groundwater recharge. Hydrol Earth Syst Sci 12: 863-885 
593

594

Döll P, Flörke M (2005) Global-scale estimation of diffuse groundwater recharge. Frankfurt Hydrology Paper 03. Institute of Physical Geography, Frankfurt University, Germany

Edmunds WM, Fellman E, Goni IB (1999) Lakes, groundwater and palaeohydrology of the Sahel of NE Nigeria: evidence from hydrochemistry. J Geol Soc 156; 345-355

Edmunds WM, Dodo A, Djoret D, Gasse F, Gaye CB, Goni IB, Travi Y, Zouari K, Zuppi GM (2004) Groundwater as an archive of climatic and environmental change. The Pep-III Traverse. In: Battarbee, RW, Gasse F, Stickley CE (eds) Past Climate Variability Through Europe and Africa. Developments In Palaeoenvironmental Research Series. Kluwer Dordrecht, pp 279-306

Foster SSD (2012) Hard rock aquifers in tropical regions: using science to inform development and management policy. Hydrogeology J 2012, Volume 20(4), Pages 659-672

Foster SSD, Chilton PJ, Moench M, Cardy F, Schiffler M (2000) Groundwater in rural development. World Bank Technical Paper 463. The World Bank, Washington DC

Frappart F, Hiernaux P, Guichard F, Mougin E, Kergoat L, Arjounin M, Lavemu F, Koite M, Paturel JP, Lebel T (2009) Rainfall regime across the Sahel band in the Gourma region, Mali. J Hydrol 375: 128-142

Favreau G (2000) Caracterisation et modelisation d'une nappe phreatique en hausse au Sahel. PhD thesis, University of Paris due Sud

Favreau G, Cappelaere B, Massuel S, Leblanc M, Boucher M, Boulain N, Leduc C (2009). Land clearing, climate variability, and water resources increase in semiarid southwest Niger : A review. Water Res Research 45 : W00A16, doi:10.1029/2007WR006785

Favreau G, Leduc C, Marlin C, Dray A, Taupin J-D, Massault M, Le Gal La Salle C, Babic M (2002) Estimate of recharge of a rising water-table in semi-arid Niger from $3 \mathrm{H}$ and $14 \mathrm{C}$ modeling. Ground Water 40(2): 144-151

Galy-Lacaux, C, Laouali D, Descroix L, Goboron N, Liousse C (2009) Long term precipitation chemistry and wet deposition in a remote dry savanna site in Africa (Niger). Atmos Chem Phys 9: 1579-7595

Gat JR (1980) The isotopes of hydrogen and oxygen in precipitation. In: Fritz P, Fontes JCh (eds) Handbook of Environmental Isotope Geochemistry. Elsevier, Amsterdam, pp 21-47

Geirnaert W, Groen M, Van der Sommen J, Leusink A (1984). Isotope studies as a final stage in groundwater investigarion on the African shield. In: Walling D E, Foster SSD, Wurzel P (eds) Challenges in African Hydrolgy and Water Resources, IAHS Publ. No. 144, pp 141-154. 
624 Global network of isotopes in precipitation -GNIP (2011). http://nds121.iaea.org/wiser/index.php.

625 Last accessed in August 2011

626 Goni IB (2006) Tracing stable isotope values from meteoric water to groundwater in the southwester

627 part of the Chad basin. Hydrogeol J 14: 742-752

628 Gooddy DC, Darling WG, Abesser C, Lapworth DJ (2006) Using chlorofluorocarbons (CFCs) and 629 sulphur hexafluoride (SF6) to characterise groundwater movement and residence time in a lowland

630 Chalk catchment. J Hydrol 330(1-2): 44-52

631 Grey D, Sadoff C (2007) Sink or swim? Water security for growth and development. Water Policy 9(6): $632 \quad 545-571$

633 Grant NK (1968) Complete late Precambrian to early Palaeozoic Orogenic cycle Togo and Dahomey. 634 Nature 215: 609-610

635 Harnisch J, Frische M, Borchers R, Eisenhauer A, Jordan A (2000) Natural fluorinated organics in 636 fluorite and rocks. Geophys Res Lett 27: 1883-1886

637 Hazell JRT, Cratchley CR, Jones CRC (1992) The hydrogeology of crystalline aquifers in northern 638 Nigeria and geophysical techniques used in their exploration. In: Wright EP, Burgess WG (eds) The 639 hydrogeology of crystalline basement aquifers in Africa. Geological Society Special Publication, $640 \quad$ No.66, pp 155-182

Heally RW, Scanlon BR (2010) Estimating Groundwater Recharge. Cambridge Press, pp 136-164 Hollander M, Wolfe DA (1973) Nonparametric Statistical Methods. New York, John Wiley \& Sons Houston JFT (1992) Rural water-supplies: comparative case histories from Nigeria and Zimbabwe.In:

644 Wright EP Burgess WG (eds) The hydrogeology of crystalline basement aquifers in Africa. Geological 645 Society Special Publication, No. 66, pp. 243-257

646 Howard G, Pedley S, Barrett M, Nalubega M, Johal K (2003) Risk factors contributing to 647 microbilogical contamination of shallow groundwater in Kampala, Uganda. Water Research 37: 34216483429.

649 Hunter PR, MacDonald AM, Carter RC (2010) Water Supply and Health. PLoS Med 7(11): e1000361. 650 doi:10.1371/journal.pmed.1000361

651 Joint Monitoring Programme -JMP (2008) Global Water Supply and Sanitation 2008 Report, Joint 652 Monitoring Programme WHO/UNICEF, World Health Organization, Geneva

653 Jones MJ (1985) The weathered zone aquifers of the basement complex areas of Africa. Q J Eng 654 Geol 18: 35-46 
Knowles L, Katz BG, Toth DJ (2010) Using multiple chemical indicators to characterize and determine the age of groundwater from selected vents of the Silver Springs Group, central Florida, USA. Hydrogeol J 18: 1825-1838

Koh DC, Plummer LN, Busenberg E, Kim Y (2007) Evidence for terrigenic $\mathrm{SF}_{6}$ in groundwater from basaltic aquifers, Jeju Island, Korea: implications for ground-water dating. J Hydrol 339: 93-104

Kundzewicz, ZW, Mata LJ, Arnell N, Döll P, Kabat P, Jiménez B, Miller K, Oki T, Şen Z, Shiklomanov I (2007) Freshwater resources and their management. Climate Change 2007: In: Parry ML, Canziani OF, Palutikof JP, van der Linden PJ, Hanson CE (eds) Impacts, Adaptation and Vulnerability. Contribution of Working Group II to the Fourth Assessment Report of the Intergovernmental Panel on Climate Change. 173-210. Cambridge University Press, UK.

Lapworth DJ, MacDonald AM, Bonsor H, Tijani MN, Calow RC (2011) Preliminary results from a Water Economy and Livelihoods Survey (WELS) in Nigeria and Mali, sub-Saharan Africa: Investigating water security across a rainfall transect. British Geological Survey Open Report (OR/11/018)

Leduc C, Favreau G, Schroeter P (2001) Long-term rise in the Sahelian water-table: the continental terminal of south-west Niger. J Hydrol 243: 43-54

Leduc C, Taupin J-D, Le Gal La Salle C (1996) Estimation of recharge in the Continential Terminal aquifer (Niamey, Niger) using Tritium (Estimation de la recharge de la nappe phréatique du Continental Terminal (Niamey, Niger) à partir des teneurs en tritium). C.R. Acad. Sci. Paris 323: 599605

Lélé IM, Lamb PJ (2010) Variability of the Intertropical Front (ITF) and Rainfall over the West African Sudan-Sahel Zone. J Climate 23: 3984-4004

MacDonald, AM, Calow RC (2009) Developing groundwater for secure rural water supplies in Africa, Desalination 248: 546-556

MacDonald AM, Calow RC, Macdonald DMJ, Darling WG, Ó Dochartaigh BÉ (2009) What impact will climate change have on rural groundwater supplies in Africa? Hydrol Sci J 54 (4): 690-703

MacDonald AM, Bonsor HC, Ó Dochartaigh BÉ, Taylor RG (2012) Quantitative maps of groundwater resources in Africa. Environ Res Lett 7: 024009. doi:10.1088/1748-9326/7/2/024009

Nicholson SE (1981) The historical climatology of Africa. In: Wigley TML, Ingram MJ, Farmer G. (eds) Climate and History, Cambridge Press, pp 249-270

Nwankwo CN, Ekine AS, Nwosu LI (2009) Estimation of the Heat Flow Variation in the Chad Basin Nigeria. J Appl Sci Environ Manag 13: 73-80 
687 Ó Dochartaigh BÉ, MacDonald AM; Darling WG, Hughes AG, Li JX; Shi LA (2010) Determining

688 groundwater degradation from irrigation in desert-marginal Northern China. Hydrogeol J 18: 1939-

$689 \quad 1952$

690 Okafor DU (1991) Hydrogeology of the River Bakogi catchment area, Niger State, Nigeria. Thesis

691 (MSc), Ahmadu Bello University, Zaria, Nigeria

692 Onuga A, Aboh HO (2009) The tritium content of precipitation and groundwater at Yola, Nigeria. Sci

693 World J 4(2): 23-28

694 Oster H (1994) Datierung von Grundwasser mittels FCKW: Voraussetzungen, Möglichkeiten und

695 Grenzen (Dating groundwater using CFCs: conditions, possibilities and limitations). Dissertation,

696 Universität Heidelberg

697 Oster H, Sonntag C, Munnich KO (1996) Groundwater age dating with chlorofluorocarbons. Water

698 Resources Res 32(10): 2989-3001

699 Parry ML, Canziani OF, Palutikof P, van der Linden PJ, Hanson CE (2007) Climate Change 2007:

700 Impacts, Adaptation and Vulnerability. Contribution of Working Group II to the Fourth Assessment

701 Report of the IPCC, Cambridge University Press, Cambridge, UK

702 Peel MC, Finlayson BL, McMahon TA (2007) Updated world map of the Köppen-Geiger climate

703 classification, Hydrol Earth Syst Sci 11: 1633-1644

704 Plummer LN, Busenberg E (1999) Chlorofluorocarbons. In: Cook PG, Herczeg AL (eds)

705 Environmental Tracers in Subsurface Hydrology. Kluwer, Dordrecht, pp.41-478.

706 Rueedi J, Brennwald MS, Purtschert R, Beyerle U, Hofer M, Kipfer R (2005) Estimating amount and

707 spatial distribution of groundwater recharge in the lullemmeden basin (Niger) based on ${ }^{3} \mathrm{H},{ }^{3} \mathrm{He}$ and

708 CFC-11 measurements. Hydrol Proc 19 (17): 3285-3298

709 Scanlon BR, Healy RW, Cook PG (2002) Choosing appropriate techniques for quantifying

710 groundwater recharge. Hydrogeol J 10: 18-39

711 Scanlon BR, Keese KE, Flint AL, Flint LE, Gaye CB, Edmunds WM, Simmers I (2006) Global

712 synthesis of groundwater recharge in semiarid and arid regions. Hydrol Proc 20: 3335-3370

713 Stadler S, Osenbrück K, Duijnisveld WHM, Schwiede M, Böttcher J (2010) Linking chloride mass

714 balance infiltration rates with chloroflurocarbon and SF6 groundwater dating in a semi-arid setting:

715 potential and limitations. Isot Environ Health Stud 46 (3): 312-324

716 Taylor C, Lambin E, Stephenne N, Harding R, Essery R (2002) The influence of land use change on

717 climate in the Sahel. J Climate 15: 3615-3629. 
718 Taylor G, Eggleton RA (2001) Regolith geology and geomorphology. Wiley \& Sons, Chichester, UK

719 Taylor RG, Howard KWF (1996) Groundwater recharge in the Victorian Nile basin of East Africa:

720 support for the soil moisture balance method using stable isotope and flow modeling studies. J Hydrol 721 180: 31-53.

722 Taylor RG, Koussis A, Tindimugaya C (2009) Groundwater and climate in Africa: a review. Hydrol Sci 723 J 54(4): 655-664

724 Taylor, R. G., Tindimugaya, C., Barker, J. A., Macdonald, D. and Kulabako, R. (2009) Convergent 725 radial tracing of viral and solute transport in gneiss saprolite. Ground Water 48: 284-294.UNTCD 726 (1988) Groundwater in North and West Africa, Natural Resources/Water Series, 18, United Nations, 727 New York

728 USGS (2012) US Geological Survey, The Reston Chlorofluorocarbon Laboratory.

729 http://water.usgs.gov/lab/software/air curve. Accessed 5 October 2012

730 Van der Sommen J, Geinaert W (1988) On the continuity of aquifer systems in the crystalline

731 basement of Burkina Faso. In: Simmers I (ed) Estimation of natural groundwater recharge, Reidel,

732 Dortrecht

Vörösmarty CJ, Green P, Sailsbury J, Lammers RB (2000) Global water resources: vulnerability from 734 climate change and population growth. Science 289 (5477): 284-288.

Wilson GB, McNeill GW (1997) Noble gas recharge temperatures and the excess air component. Appl

736 Geochem 12: 747-762.

Wright EP (1992) The hydrogeology of crystalline basement aquifers in Africa. In: Wright EP, Burgess WG (eds) The Hydrogeology of Crystalline Basement Aquifers in Africa, vol. 66, Geological Society London Special Publications, pp. 1-27

Zuber A (1986) Mathematical models for the interpretation of environmental radioisotopes in groundwater systems. In: Fritz P, Fontes J-C (eds), Handbook of Environmental Isotope Geochemistry, vol. 2. Elsevier, Amsterdam, pp. 1-59

FIGURE CAPTIONS:

749

750

Fig. 1 Location and geology map of the four study areas across the West African transect. Areas colored black show young volcanics 
Fig. 2 Cross-plot of $\delta^{18} \mathrm{O}$ vs $\delta^{2} \mathrm{H}$. The Global Meteoric Water Line (GMWL) is shown as the dashed line on the plot. For comparison, the dashed area shows where shallow groundwater values plot from NE Nigeria (Edmunds et al. 1999), the solid area show where values plot for groundwaters from central Nigeria (Adanu 1991)

757

Fig. 3 Box-plots showing variations in (a) ${ }^{3} \mathrm{H}$ for shallow groundwaters within the sedimentary and basement aquifers across the rainfall transect (b) MRT for the four study areas, calculated from mainly $\mathrm{SF}_{6}$ data, and some $\mathrm{CFC}-12$ data where suitable, using the exponential mixing model. The horizontal dashed line in Fig. $3 \mathrm{~b}$ is the median MRT value for all the results in this study

Fig. 5 Cumulative probability plot of mean residence times (MRT) for shallow groundwaters within sedimentary (open circles) and basement (filled circles) aquifers across all four study areas. An exponential mixing model was used to calculate MRT.

Fig. 6 Conceptual diagram of groundwater recharge processes in arid zones for (a) basement and (b) sedimentary aquifers, explaining similar MRT results. Typical permeability ranges from Wright (1992) and Allen et al. (1997)

Fig. 7 Conceptual diagram of groundwater recharge and flow processes in basement aquifers for (a) humid zones and (b) arid zones. Arrows are only indicative of fluxes, $\mathrm{PE}=$ potential evaporation, $\mathrm{ET}=$ evapotranspiration 


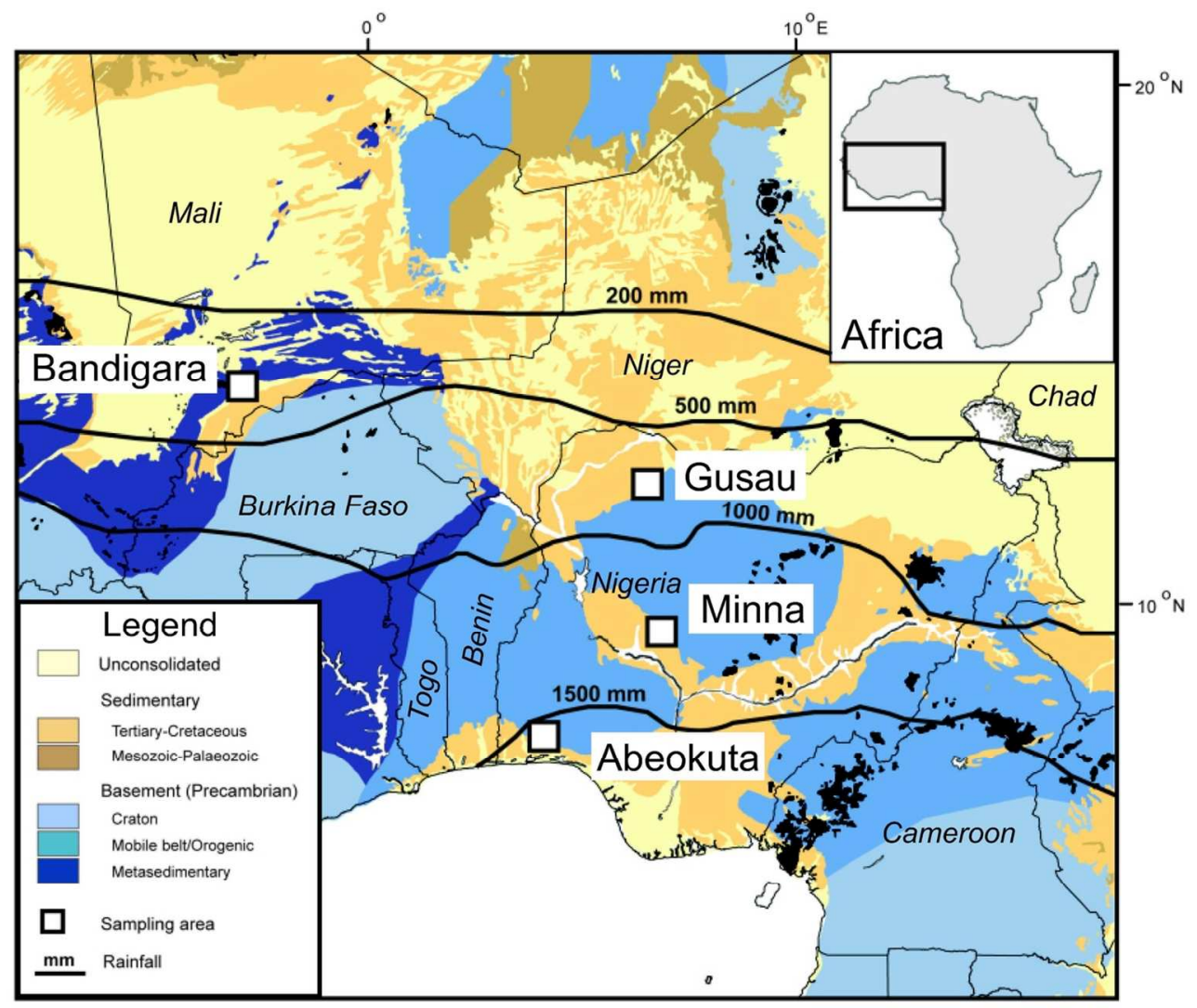

Fig. 1 Location and geology map of the four study areas across the West African transect. Areas colored black show young volcanics $123 \times 103 \mathrm{~mm}(300 \times 300 \mathrm{DPI})$ 


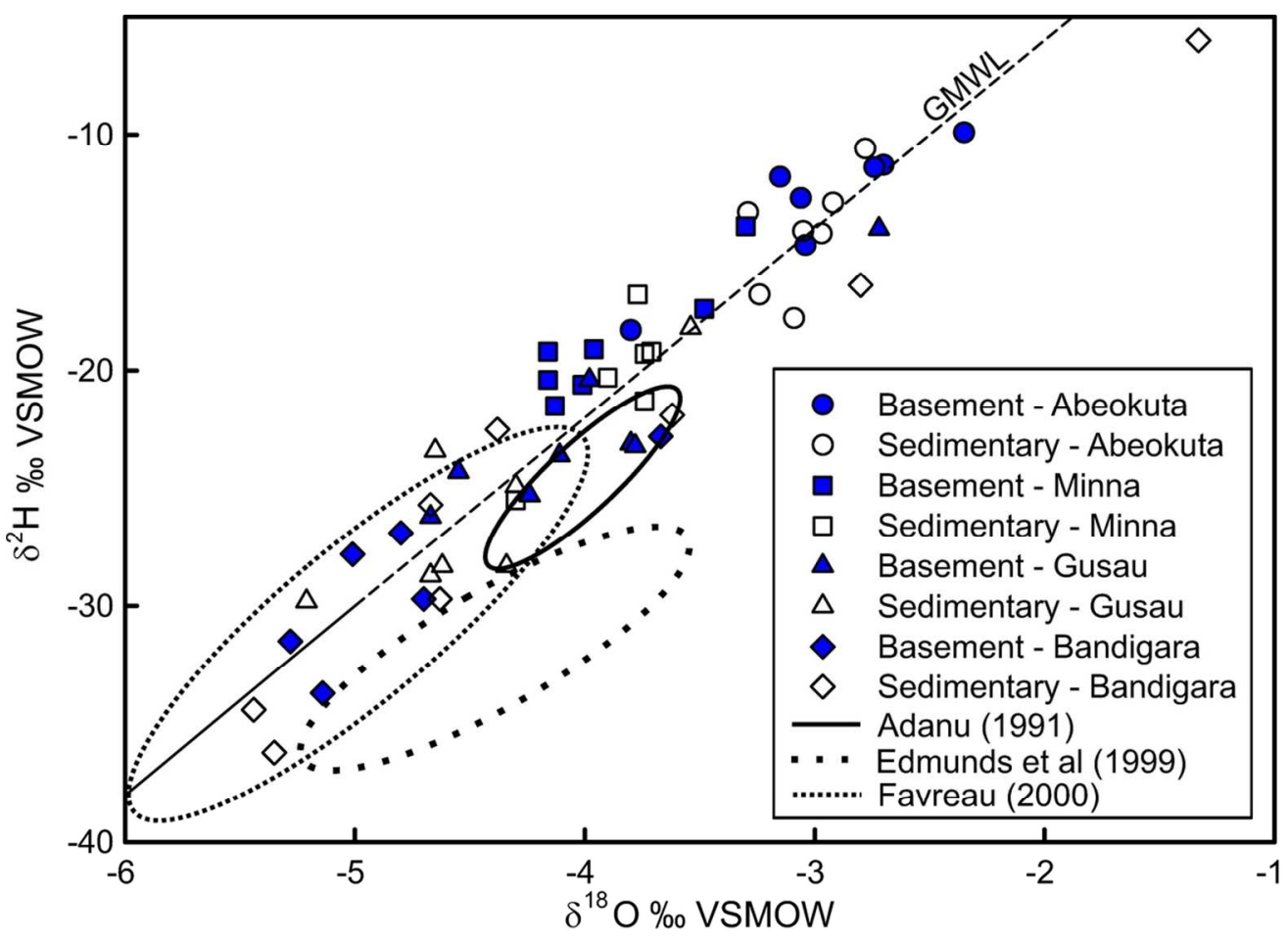

Fig. 2 Cross-plot of $\delta 180$ vs $\delta 2 \mathrm{H}$. The Global Meteoric Water Line (GMWL) is shown as the dashed line on the plot. For comparison, the dashed area shows where shallow groundwater values plot from NE Nigeria (Edmunds et al. 1999), the solid area show where values plot for groundwaters from central Nigeria (Adanu 1991)

$109 \times 78 \mathrm{~mm}(300 \times 300 \mathrm{DPI})$ 


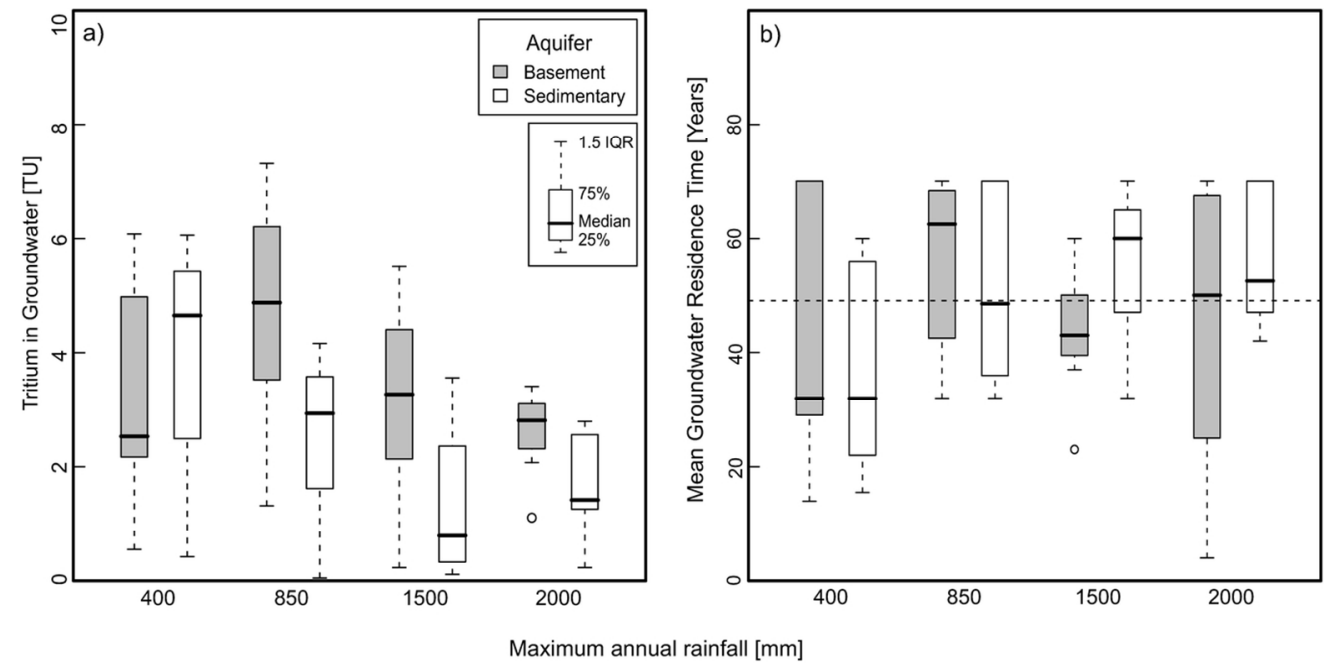

Fig. 3 Box-plots showing variations in (a) $3 \mathrm{H}$ for shallow groundwaters within the sedimentary and basement aquifers across the rainfall transect (b) MRT for the four study areas, calculated from mainly SF6 data, and some CFC-12 data where suitable, using the exponential mixing model. The horizontal dashed line in Fig. $3 \mathrm{~b}$ is the median MRT value for all the results in this study $114 \times 57 \mathrm{~mm}(300 \times 300 \mathrm{DPI})$ 

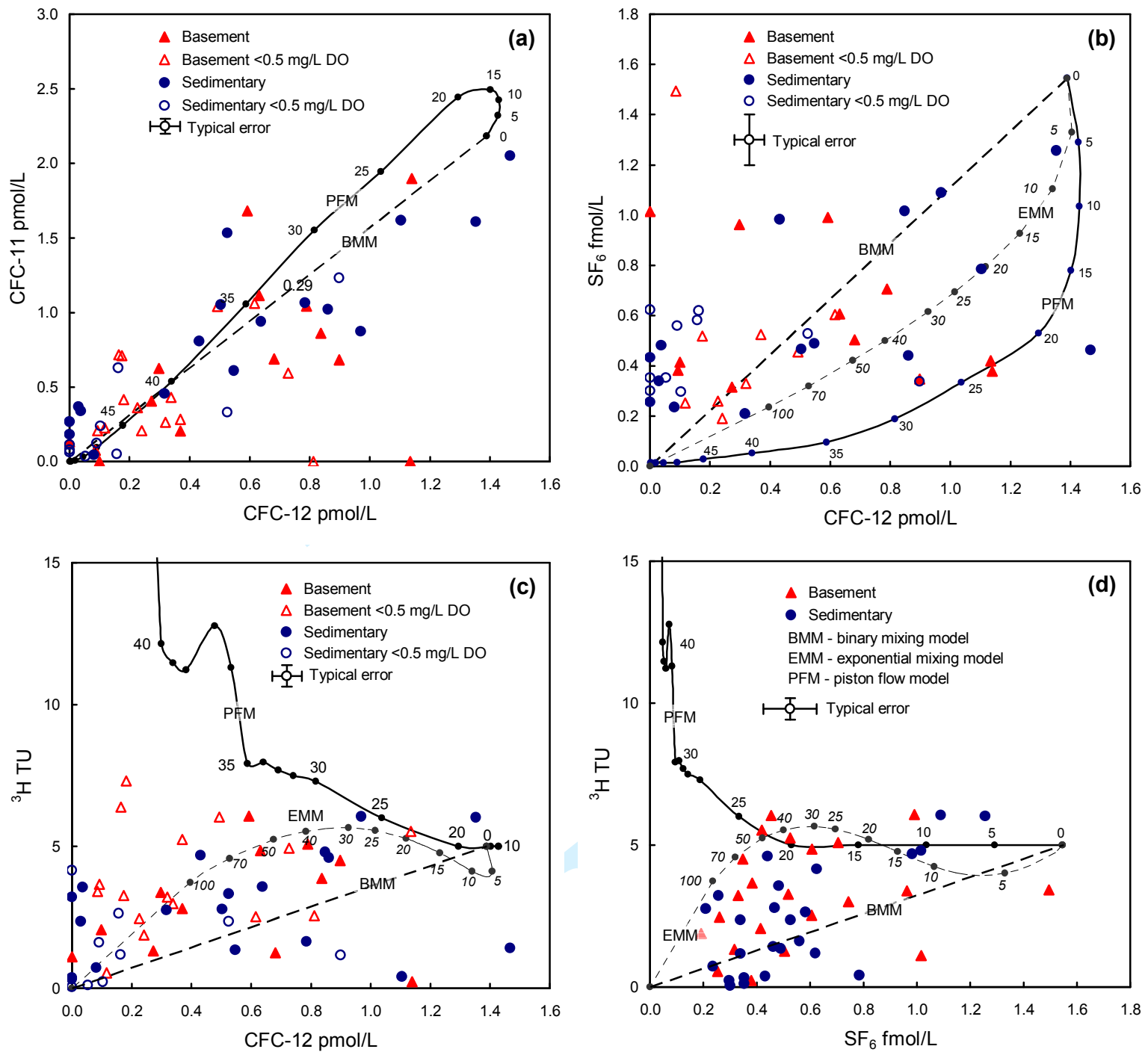

Fig. 4 Residence time tracer results in shallow groundwater (a) co-plot of CFC-12 and CFC-11, (b) co-plot of CFC-12 and SF6, (c) co-plot of CFC-12 and 3H and (d) co-plot of SF6 and 3H. Lumped parameter model curves are shown on each plot based on http://water.usgs.gov/lab/software/air_curve/ for the CFCs and

SF6 and Leduc et al. (1996), Onuga and Aboh (2009) and GNIP (2011) for tritium. The values beside the piston flow model (PFM, solid line) and exponential mixing model (EMM, short dashed line) curves in each plot shows modelled residence times in years. Symbols: Open symbols show sites with dissolved oxygen (DO) is $<0.5 \mathrm{mg} / \mathrm{L}$, filled symbols are sites with DO $>0.5$ $\mathrm{mg} / \mathrm{L}$. Triangles are sites on the Basement geology, circles sites on the Sedimentary geology 


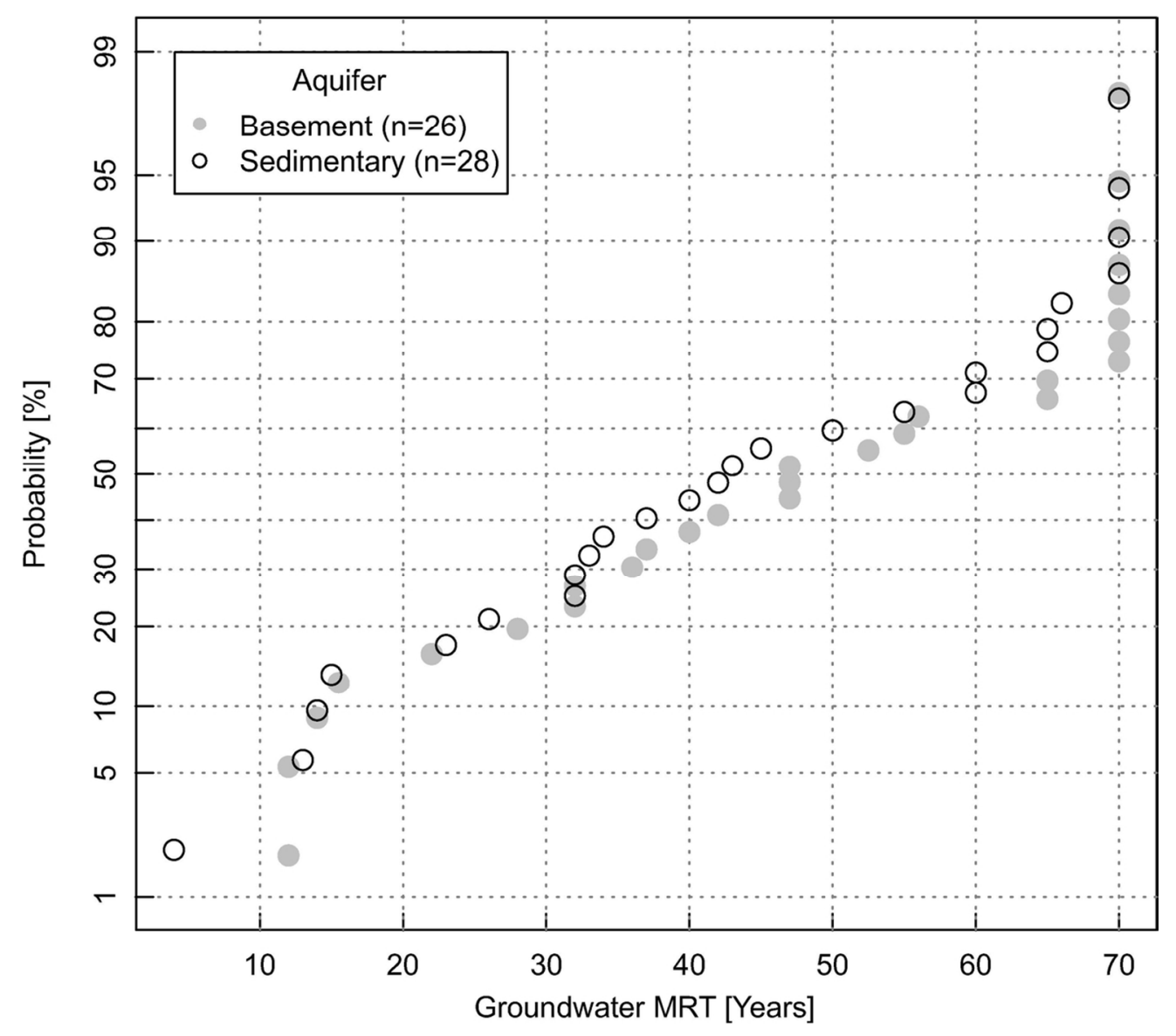

Fig. 5 Cumulative probability plot of mean residence times (MRT) for shallow groundwaters within sedimentary (open circles) and basement (filled circles) aquifers across all four study areas. An exponential mixing model was used to calculate MRT. $112 \times 99 \mathrm{~mm}(300 \times 300 \mathrm{DPI})$ 

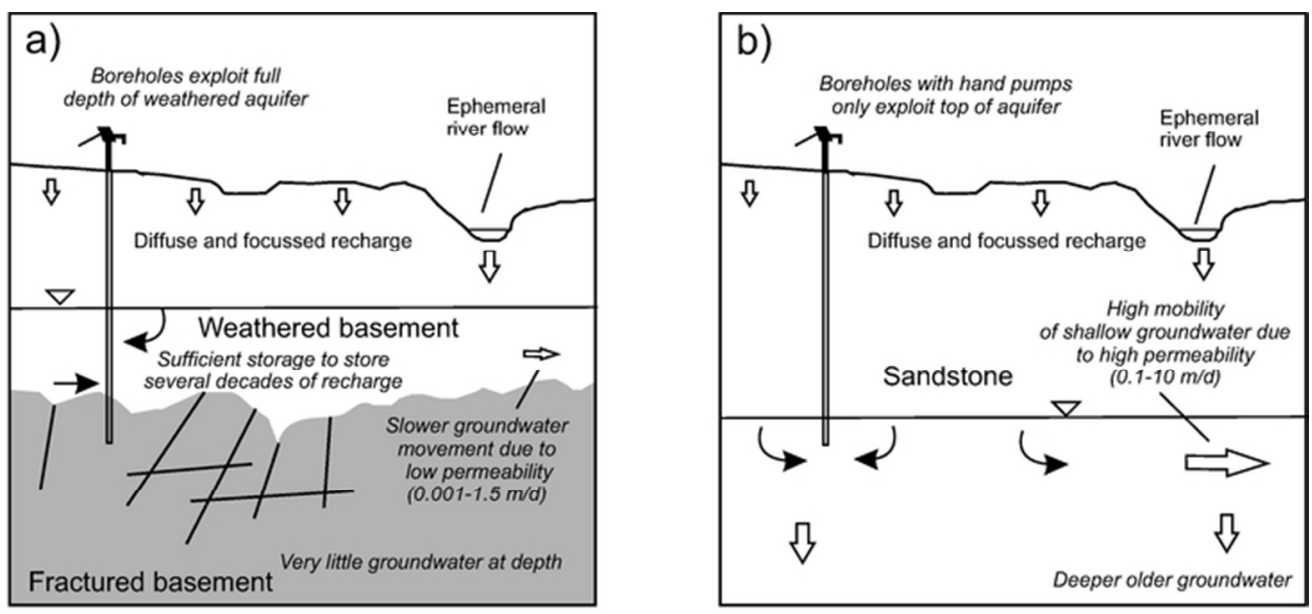

Fig. 6 Conceptual diagram of groundwater recharge processes in arid zones for (a) basement and (b) sedimentary aquifers, explaining similar MRT results. Typical permeability ranges from Wright (1992) and Allen et al. (1997)

$61 \times 28 \mathrm{~mm}(300 \times 300 \mathrm{DPI})$ 

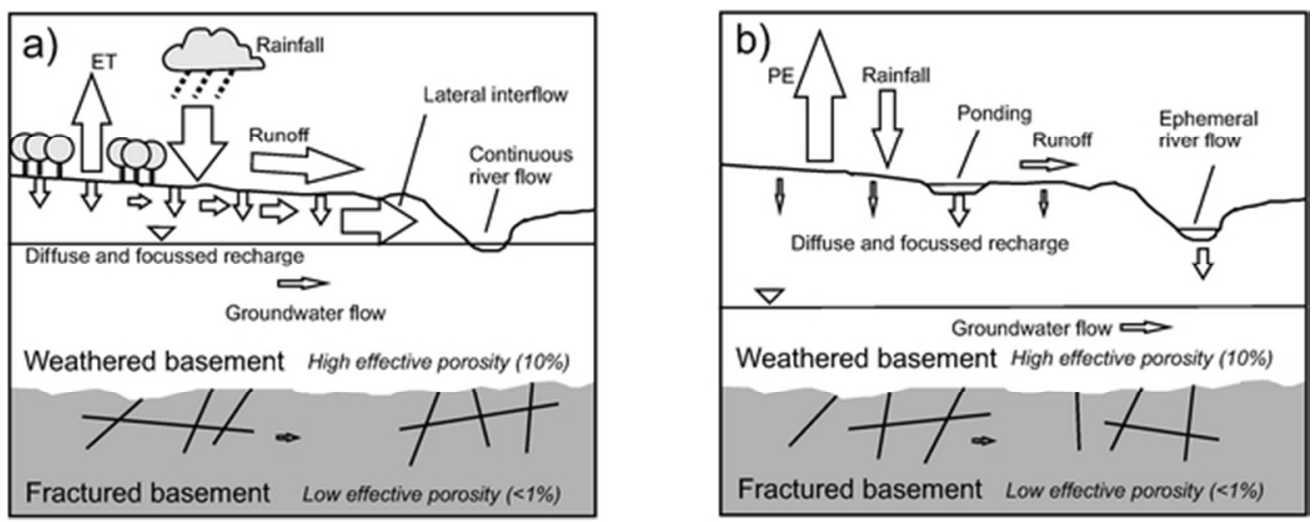

Fig. 7 Conceptual diagram of groundwater recharge and flow processes in basement aquifers for (a) humid zones and (b) arid zones. Arrows are only indicative of fluxes, PE = potential evaporation, ET = evapotranspiration

$52 \times 20 \mathrm{~mm}(300 \times 300$ DPI $)$ 
Table 1 Study area summary information: Climate, population, livelihood, land use, number of hand pumps sampled, rest water level and borehole depths across the rainfall transect. Climate zone classification from Peel et al. (2007), population data from Lapworth et al. (2011)

\begin{tabular}{|c|c|c|c|c|c|c|c|}
\hline $\begin{array}{l}\text { Climate zone }{ }^{ \pm} \\
\text {(average rainfall) }\end{array}$ & $\begin{array}{l}\text { Country and region }{ }_{2} t \\
\text { Case study }\end{array}$ & Length of dry season & $\begin{array}{l}\text { Average (range) village } \\
\text { population }\end{array}$ & $\begin{array}{l}\text { Av. Population } \\
\text { increase in last } 5 \\
\text { years }\end{array}$ & Sites+ & $\begin{array}{l}\text { RWL range } \\
(\mathrm{mbgl})+\end{array}$ & $\begin{array}{l}\text { Borehole depth } \\
\text { range }(\mathrm{mbgl})+\end{array}$ \\
\hline $\begin{array}{l}\mathrm{Am} \\
(1800-2000 \mathrm{~mm} / \mathrm{y})\end{array}$ & Nigeria, Abeokuta* & $\begin{array}{l}\text { 3-4 months } \\
\text { (Oct-Jan) }\end{array}$ & $2300(200-5000)$ & $34 \%$ & $7(7)$ & $<10(3.5-20)$ & $30-40(20-70)$ \\
\hline $\begin{array}{l}\text { Aw } \\
(1200-1500 \mathrm{~mm} / \mathrm{y})\end{array}$ & Nigeria $_{2}$ Minna* & $\begin{array}{l}\text { 7-8 months } \\
\text { (Sep-May) }\end{array}$ & $1100(100-2000)$ & $40 \%$ & $7(6)$ & $<10(7.5-10)$ & $20-30(30-40)$ \\
\hline $\begin{array}{l}\text { BSh } \\
(700-850 \mathrm{~mm} / \mathrm{y})\end{array}$ & Nigeria, Gusau** & $\begin{array}{l}\text { 7-8 months } \\
\text { (Sep-May) }\end{array}$ & $2300(500-5000)$ & $36 \%$ & $8(6)$ & $<10-20(9-15)$ & $20-42(25-30)$ \\
\hline $\begin{array}{l}\text { BWh } \\
(350-400 \mathrm{~mm} / \mathrm{y})\end{array}$ & Mali, Bandigara** & $\begin{array}{l}9 \text { months } \\
\text { (Oct-Jun) }\end{array}$ & $2000(420-7000)$ & $14 \%$ & $7(5)$ & $8-10(8-20)$ & $15-62(25-76)$ \\
\hline
\end{tabular}

Table 2 Summary groundwater tracer results in the shallow basement and sedimentary aquifers within the four case study areas: stable isotopes $\left(\delta^{18} \mathrm{O}, \delta^{2} \mathrm{H}\right)$ residence time tracers (CFC-12, CFC-11, $\mathrm{SF}_{6}$ and ${ }^{3} \mathrm{H}$ ) estimated mean residence time (MRT), field $\mathrm{DO}_{2}$ and $\mathrm{Cl}$

\begin{tabular}{lccccccccc}
\hline & $\begin{array}{l}\delta^{18} \mathrm{O} \\
\% \text { VSMOW }\end{array}$ & $\begin{array}{c}\delta^{2} \mathrm{H} \\
\mathrm{Cmol}-\mathrm{L}\end{array}$ & $\begin{array}{c}\mathrm{CFC}-11 \\
\mathrm{pmol} / \mathrm{L}\end{array}$ & $\begin{array}{c}\mathrm{SF}_{6} \\
\mathrm{fmol} / \mathrm{L}\end{array}$ & $\begin{array}{c}{ }^{3} \mathrm{H} \\
\mathrm{TU}\end{array}$ & $\begin{array}{c}\mathrm{MRT}^{* *} \\
\text { Years }\end{array}$ & $\begin{array}{c}\mathrm{DO}_{2} \\
\mathrm{mg} / \mathrm{L}\end{array}$ & $\begin{array}{c}\mathrm{Cl} \\
\mathrm{mg} / \mathrm{L}\end{array}$ \\
\hline Basement & & & & & & & & & \\
Abeokuta, Nigeria & & & & & & & & \\
Mean & -3.0 & -12.9 & 0.34 & 0.43 & 1.92 & 2.59 & 34 & 2.46 & 45.0 \\
Median & -3.0 & -11.8 & 0.33 & 0.25 & 1.41 & 2.81 & 37 & 1.07 & 37.3 \\
SD & 0.5 & 2.8 & 0.26 & 0.55 & 1.82 & 0.79 & 25 & 3.21 & 34.2 \\
Min & -3.8 & -18.3 & 0.09 & 0.08 & 0.31 & 1.11 & 4 & 0.03 & 3.4
\end{tabular}




\begin{tabular}{|c|c|c|c|c|c|c|c|c|c|}
\hline Max & -2.4 & -9.9 & 0.81 & 1.64 & 5.55 & 3.41 & 65 & 7.61 & 103.9 \\
\hline \multicolumn{10}{|c|}{ Minna, Nigeria } \\
\hline Mean & -3.9 & -18.9 & 0.92 & 1.00 & 1.24 & 3.16 & 43 & 2.36 & 3.5 \\
\hline Median & -4.0 & -19.2 & 0.84 & 0.86 & 0.49 & 3.27 & 43 & 1.92 & 0.2 \\
\hline SD & 0.4 & 2.6 & 0.48 & 0.45 & 1.53 & 1.89 & 14 & 1.70 & 8.0 \\
\hline Min & -4.2 & -21.5 & 0.17 & 0.59 & 0.36 & 0.23 & 23 & 0.49 & 0.1 \\
\hline Max & -3.3 & -13.9 & 1.73 & 1.90 & 4.53 & 5.52 & 60 & 5.15 & 21.6 \\
\hline \multicolumn{10}{|c|}{ Gusau, Nigeria } \\
\hline Mean & -4.0 & -22.5 & 0.35 & 0.55 & 3.32 & 4.73 & 46 & 0.66 & 7.8 \\
\hline Median & -4.0 & -23.4 & 0.28 & 0.52 & 0.46 & 4.87 & 45 & 0.29 & 4.6 \\
\hline SD & 0.6 & 3.8 & 0.26 & 0.27 & 6.58 & 1.93 & 19 & 0.65 & 10.1 \\
\hline Min & -4.7 & -26.2 & 0.09 & 0.21 & 0.30 & 1.32 & 15 & 0.03 & 0.8 \\
\hline Max & -2.7 & -14.0 & 0.90 & 1.04 & 19.21 & 7.31 & 66 & 1.64 & 31.8 \\
\hline \multicolumn{10}{|c|}{ Bandigara, Mali } \\
\hline Mean & -5.0 & -30.2 & 0.46 & 0.81 & 0.49 & 3.35 & 41 & 0.57 & 4.2 \\
\hline Median & -5.0 & -29.7 & 0.59 & 1.04 & 0.57 & 2.53 & 32 & 0.33 & 2.8 \\
\hline SD & 0.7 & 5.1 & 0.26 & 0.56 & 0.28 & 2.01 & 24 & 0.59 & 3.1 \\
\hline Min & -6.1 & -38.7 & 0.12 & 0.21 & 0.18 & 0.55 & 14 & 0.05 & 2.1 \\
\hline Max & -3.7 & -22.8 & 0.79 & 1.68 & 0.93 & 6.08 & 70 & 1.54 & 10.6 \\
\hline \multicolumn{10}{|c|}{ Sedimentary } \\
\hline \multicolumn{10}{|c|}{ Abeokuta, Nigeria } \\
\hline Mean & -3.0 & -14.2 & 0.62 & 0.85 & 0.37 & 1.73 & 55 & 2.46 & 11.6 \\
\hline Median & -3.1 & -14.1 & 0.53 & 0.61 & 0.43 & 1.42 & 50 & 1.09 & 8.0 \\
\hline SD & 0.2 & 2.4 & 0.44 & 0.65 & 0.11 & 0.95 & 12 & 2.43 & 8.5 \\
\hline Min & -3.3 & -17.8 & 0.10 & 0.22 & 0.19 & 0.23 & 42 & 0.41 & 3.9 \\
\hline Max & -2.8 & -10.6 & 1.47 & 2.05 & 0.49 & 2.79 & 70 & 6.10 & 24.3 \\
\hline \multicolumn{10}{|c|}{ Minna, Nigeria } \\
\hline Mean & -3.9 & -20.4 & 0.07 & 0.33 & 0.40 & 1.32 & 56 & 2.11 & 1.8 \\
\hline Median & -3.8 & -19.8 & 0.04 & 0.34 & 0.36 & 0.79 & 60 & 2.50 & 1.2 \\
\hline SD & 0.2 & 2.9 & 0.06 & 0.20 & 0.10 & 1.37 & 14 & 1.85 & 1.9 \\
\hline
\end{tabular}




\begin{tabular}{lccccccccc} 
Min & -4.3 & -25.5 & 0.03 & 0.11 & 0.31 & 0.11 & 32 & 0.05 & 0.2 \\
Max & -3.7 & -16.8 & 0.16 & 0.63 & 0.57 & 3.56 & 70 & 4.70 & 4.8 \\
\multicolumn{2}{l}{ Gusau, Nigeria } & & & & & & & & \\
Mean & -4.5 & -25.9 & 0.24 & 0.28 & 0.64 & 2.55 & 33 & 1.99 & 6.3 \\
Median & -4.6 & -28.3 & 0.12 & 0.12 & 0.52 & 2.93 & 34 & 1.05 & 1.1 \\
SD & 0.5 & 4.1 & 0.27 & 0.32 & 0.68 & 1.50 & 4 & 2.31 & 9.8 \\
Min & -5.2 & -29.8 & 0.08 & 0.05 & 0.21 & 0.05 & 28 & 0.05 & 0.3 \\
Max & -3.5 & -18.2 & 0.64 & 0.94 & 2.16 & 4.16 & 37 & 5.71 & 25.4 \\
Bandigara, Mali & & & & & & & & \\
Mean & -4.0 & -24.1 & 0.86 & 0.97 & 3.72 & 3.95 & 30 & 2.79 & 12.7 \\
Median & -4.5 & -24.1 & 0.85 & 0.95 & 0.97 & 4.65 & 19 & 2.72 & 11.2 \\
SD & 1.4 & 9.9 & 0.30 & 0.47 & 6.79 & 2.02 & 23 & 2.09 & 6.3 \\
Min & -5.4 & -36.2 & 0.43 & 0.16 & 0.41 & 0.42 & 12 & 0.55 & 2.2 \\
Max & -1.3 & -6.0 & 1.35 & 1.62 & 20.25 & 6.06 & 70 & 6.87 & 21.1 \\
\hline * MRT calculed
\end{tabular}

*MRT calculated using an exponential mixing model, $\mathrm{SD}=$ Standard deviation 
Residence times of shallow groundwater in West Africa: implications for hydrogeology and resilience to future changes in climate

Lapworth D.J ${ }^{a}$, MacDonald A.M ${ }^{b}$, Tijani M.N ${ }^{c}$, Darling W.G ${ }^{a}$, Gooddy D.C ${ }^{a}$, Bonsor H.C ${ }^{b}$, AraguásAraguás L.J ${ }^{d}$

${ }^{a}$ British Geological Survey, Wallingford, OX10 8BB, UK

${ }^{\mathrm{b}}$ British Geological Survey, Edinburgh, EH9 3LA, UK

' University of Ibadan, Department of Geology, Nigeria

${ }^{\mathrm{d}}$ International Atomic Energy Agency, Vienna

*Corresponding author

e-mail: djla@bgs.ac.uk

Tel: $+44(0) 1491692327$

Fax: $+44(0) 1491692345$

\section{Electronic Supplementary material:}

Fig. S1 Rainfall ${ }^{3} \mathrm{H}$ curve derived for West Africa. Data from the GNIP (2011; see References in the main article) combined with measurements by Leduc et al. (1996) and Onuga and Aboh (2009)

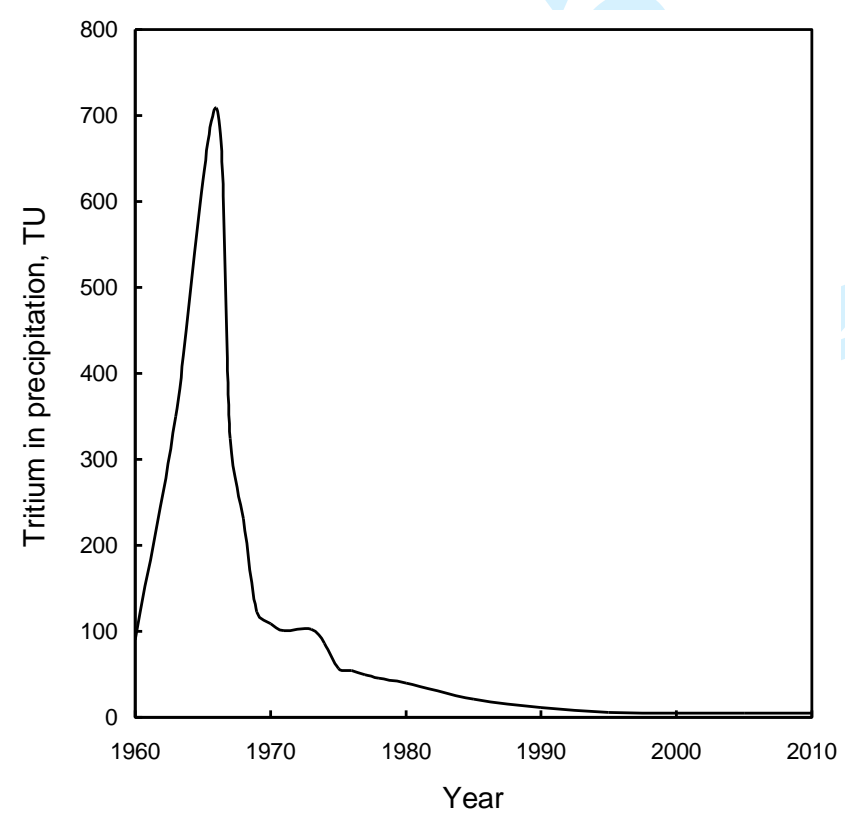


Fig. S2 Variation over time in (a) Northern hemisphere atmospheric mixing ratio curves for CFC-11, $\mathrm{CFC}-12$ and $\mathrm{SF}_{6}$ based on $\mathrm{CMDL} / \mathrm{NOAA}$ data. (a) groundwater concentrations assuming equilibrium with Northern Hemisphere mixing ratios and recharge temperatures of $28^{\circ} \mathrm{C}$. Note differences in scales between $\mathrm{CFCs}$ and $\mathrm{SF}_{6}$

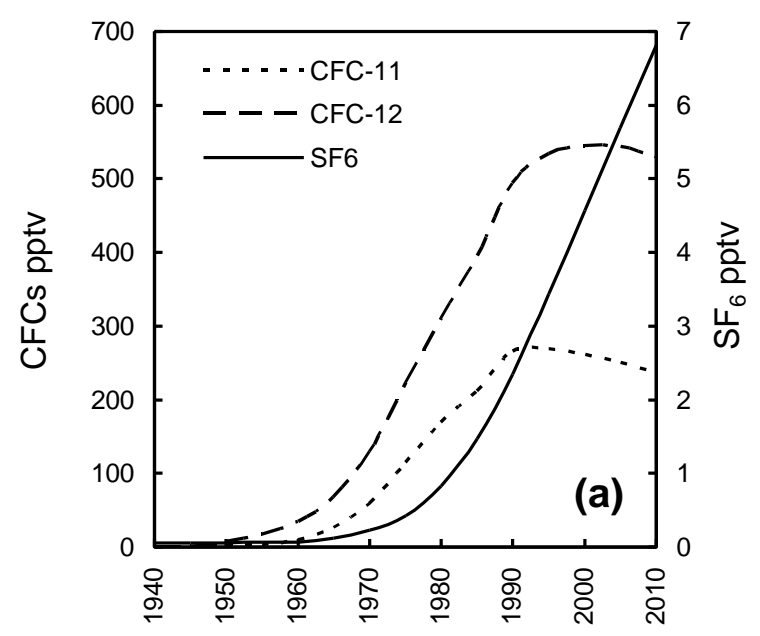

Year

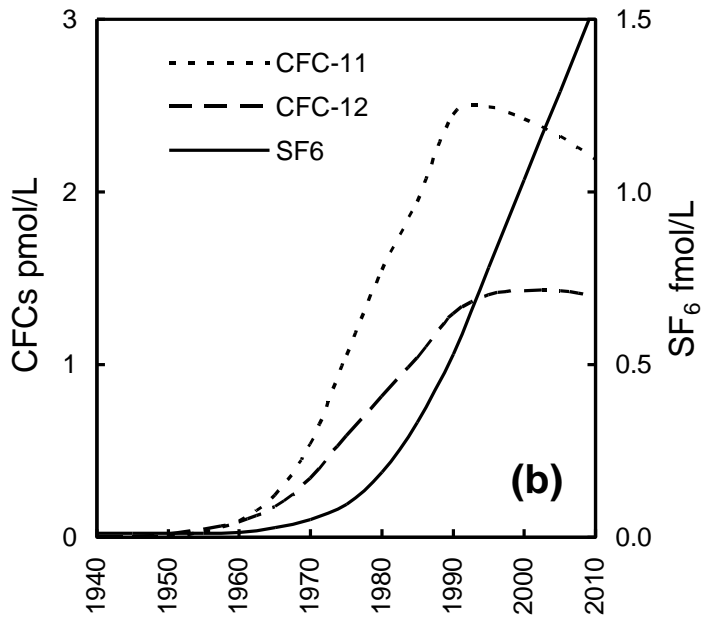

Year 
Table S1. Groundwater chemistry results in the shallow basement and sedimentary aquifers within the four West African study areas: field chemistry (temperature, $\left.\mathrm{pH}, \mathrm{SEC}, \mathrm{DO}_{2}\right)$, stable isotopes $\left(\delta^{18} \mathrm{O}\right.$, $\left.\delta^{2} \mathrm{H}\right)$ and residence time tracers $\left(\mathrm{CFC}-12, \mathrm{CFC}-11, \mathrm{SF}_{6}\right.$ and $\left.{ }^{3} \mathrm{H}\right)$ and estimated mean residence time (MRT)

\begin{tabular}{|c|c|c|c|c|c|c|c|c|c|c|c|c|c|}
\hline Site ID & Geol.* & $\begin{array}{l}\mathrm{T} \\
{ }^{\circ} \mathrm{C} \\
\end{array}$ & $\mathrm{pH}$ & $\begin{array}{c}\text { SEC } \\
\mu \mathrm{S} \cdot \mathrm{cm}^{-1} \\
\end{array}$ & $\begin{array}{r}\mathrm{DO}_{2} \\
\mathrm{mg} \cdot \mathrm{L}^{-1} \\
\end{array}$ & $\begin{array}{c}\mathrm{Cl} \\
\mathrm{mg} \cdot \mathrm{L}^{-1}\end{array}$ & $\begin{array}{l}\delta^{18} \mathrm{O} \\
\% \mathrm{VSS} \\
\end{array}$ & $\begin{array}{l}\delta^{2} \mathrm{H} \\
\text { ow }\end{array}$ & $\begin{array}{l}\text { CFC-12 } \\
\text { pmol. } L^{-1}\end{array}$ & $\begin{array}{l}\text { CFC-11 } \\
\text { pmol. } \mathrm{L}^{-1}\end{array}$ & $\begin{array}{c}\mathrm{SF}_{6} \\
\mathrm{fmol} \cdot \mathrm{L}^{-1}\end{array}$ & $\begin{array}{l}{ }^{3} \mathrm{H} \\
\mathrm{TU} \\
\end{array}$ & $\begin{array}{c}\mathrm{MRT}^{* *} \\
\text { Years }\end{array}$ \\
\hline \multicolumn{14}{|c|}{ Abeokuta, Nigeria } \\
\hline B13 & B & 29.5 & 6.66 & 502 & 7.61 & 20.7 & -3.15 & -11.8 & $<0.01$ & 0.13 & 0.96 & 1.11 & 13 \\
\hline B14 & B & 29.5 & 7.01 & 705 & $<0.05$ & 3.4 & -2.35 & -9.9 & 0.81 & 0.25 & 5.55 & 2.56 & 37 \\
\hline B15 & B & 28.9 & 6.01 & 610 & 3.51 & 60.8 & -2.7 & -11.3 & 0.10 & 1.64 & 0.39 & 2.07 & 50 \\
\hline B16 & B & 27.3 & 5.45 & 535 & $<0.05$ & 103.9 & -3.06 & -12.7 & 0.32 & 0.26 & 0.31 & 3.21 & 65 \\
\hline B17 & B & 29.6 & 6.16 & 437 & 0.03 & 37.3 & -3.04 & -14.7 & 0.09 & 0.08 & 1.41 & 3.41 & 4 \\
\hline B18 & B & 27.7 & 5.53 & 234 & 0.06 & 22.8 & -3.8 & -18.3 & 0.34 & 0.43 & 2.62 & 2.99 & $\mathrm{~N} / \mathrm{A}$ \\
\hline B19 & B & 27 & 5.75 & 670 & 1.07 & 66.2 & -2.74 & -11.4 & 0.37 & 0.20 & 2.22 & 2.81 & $>70$ \\
\hline $\mathrm{A} 17^{\mathrm{a}}$ & s & 29.2 & 4.55 & 32.1 & 1.09 & 3.9 & -2.97 & -14.2 & 0.55 & 0.61 & 0.45 & 1.35 & 52.5 \\
\hline $\mathrm{A} 18^{\mathrm{a}}$ & S & 28.8 & 5.21 & 251 & 5.32 & 22.3 & -2.78 & -10.6 & 0.50 & 1.05 & 0.43 & 2.79 & 47 \\
\hline $\mathrm{A} 19^{\mathrm{a}}$ & $S$ & 30.1 & 6.24 & 431 & 0.41 & 24.3 & -3.24 & -16.8 & 0.10 & 0.22 & 0.27 & 0.23 & $>70$ \\
\hline $\mathrm{A} 20^{\mathrm{a}}$ & S & 28.2 & 4.49 & 46.8 & 0.64 & 5.2 & -3.05 & -14.1 & 0.90 & 1.23 & 0.31 & 1.17 & 70 \\
\hline A21 & $S$ & 26.8 & 5.96 & 206 & 0.45 & 12.8 & -2.92 & -12.9 & 0.53 & 0.33 & 0.49 & 2.36 & 42 \\
\hline $\mathrm{A} 22^{\mathrm{a}}$ & $S$ & 27.6 & 4.23 & 51.6 & 3.18 & 8.0 & -3.09 & -17.8 & 0.32 & 0.46 & 0.19 & 2.76 & 70 \\
\hline $\mathrm{A} 23^{\mathrm{a}}$ & $S$ & 27.8 & 4.64 & 45.8 & 6.1 & 4.8 & -3.29 & -13.3 & 1.47 & 2.05 & 0.43 & 1.42 & 47 \\
\hline \multicolumn{14}{|c|}{ Minna, Nigeria } \\
\hline $\mathrm{A} 1$ & B & 31.4 & 5.96 & 199.7 & 2.72 & 1.6 & -3.48 & -17.4 & 0.84 & 0.86 & 4.53 & 3.87 & 34 \\
\hline A2 & B & 30.3 & 5.87 & 170.8 & 0.49 & 0.1 & -3.3 & -13.9 & 0.73 & 0.59 & 1.77 & 4.93 & $N / A$ \\
\hline A3 & B & 28.6 & 6.42 & 394 & 1.72 & 0.6 & -4.16 & -19.2 & 1.73 & 1.20 & 0.70 & 3.01 & 23 \\
\hline A4 & B & 28.9 & 6.26 & 238 & 0.65 & 0.1 & -4.13 & -21.5 & 1.13 & 1.08 & 0.40 & 5.52 & 55 \\
\hline A5 & B & 31.4 & 6.96 & 363 & 5.15 & 0.2 & -4.16 & -20.4 & 1.14 & 1.90 & 0.36 & 0.23 & 60 \\
\hline B1 & B & 28.3 & 6.32 & 359 & 1.92 & 21.6 & -4.01 & -20.6 & 0.17 & 0.71 & 0.49 & 3.27 & 42 \\
\hline B2 & B & 30.1 & 6.28 & 233 & 3.89 & 0.1 & -3.96 & -19.1 & 0.68 & 0.69 & 0.48 & 1.26 & 43 \\
\hline A6 & $s$ & 30.7 & 5.19 & 55.2 & 4.7 & 1.7 & -3.77 & -16.8 & 0.03 & 0.37 & 0.31 & 2.36 & 70 \\
\hline A7 & $S$ & 31.3 & 6.04 & 196 & 2.7 & 3.5 & -3.9 & -20.3 & $<0.01$ & 0.18 & 0.40 & 0.38 & 55 \\
\hline A8 & $S$ & 31.2 & 5.55 & 126.7 & 2.5 & 4.8 & -3.74 & -19.3 & 0.04 & 0.34 & 0.44 & 3.56 & 47 \\
\hline B3 & $S$ & 30.7 & 5.99 & 236 & $<0.05$ & 0.2 & -4.3 & -25.5 & $<0.01$ & 0.11 & 0.33 & 0.33 & 65 \\
\hline B4 & $S$ & 31.3 & 5.72 & 104.7 & 0.6 & 0.7 & -3.71 & -19.2 & 0.16 & 0.63 & 0.57 & 1.2 & 32 \\
\hline B5 & $S$ & 30.9 & 5.67 & 104 & 0.05 & 0.2 & -3.74 & -21.3 & 0.05 & $<0.05$ & 0.33 & 0.11 & 65 \\
\hline \multicolumn{14}{|c|}{ Gusau, Nigeria } \\
\hline A9 & B & 29.9 & 6.56 & 629 & 0.22 & 31.8 & -3.8 & -23.1 & 0.16 & 0.72 & 0.49 & 6.38 & 40 \\
\hline $\mathrm{A} 10$ & B & 30.6 & 6.53 & 148.2 & 0.03 & 0.8 & -3.78 & -23.2 & 0.37 & 0.28 & 0.43 & 5.24 & 45 \\
\hline A11 & B & 30.9 & 6.59 & 220 & 0.33 & 6.9 & -4.55 & -24.3 & 0.49 & 1.04 & 0.33 & 6.04 & 65 \\
\hline A12 & B & 32 & 6.6 & 353 & 1.46 & 3.7 & -4.11 & -23.6 & 0.90 & 0.68 & 19.21 & 4.5 & 33 \\
\hline B6 & B & 29.3 & 6.08 & 282 & 1.64 & 9.4 & -4.24 & -25.3 & 0.30 & 0.63 & 0.91 & 3.39 & 15 \\
\hline B7 & B & 31.1 & 6.78 & 542 & 0.18 & 4.4 & -4.67 & -26.2 & 0.18 & 0.41 & 4.53 & 7.31 & $\mathrm{~N} / \mathrm{A}$ \\
\hline B8 & B & 30.7 & 5.88 & 115.1 & 1.15 & 0.9 & -3.98 & -20.4 & 0.27 & 0.40 & 0.30 & 1.32 & 66 \\
\hline B9 & B & 30.6 & 6.19 & 148.8 & 0.24 & 4.8 & -2.72 & -14 & 0.09 & 0.21 & 0.36 & 3.66 & 60 \\
\hline A13 & $S$ & 32.3 & 7 & 631 & 5.71 & 13.9 & -4.67 & -28.7 & 0.64 & 0.94 & 2.16 & 3.58 & 28 \\
\hline A14 & $S$ & 29.6 & 6.41 & 255 & 0.38 & 2.2 & -3.54 & -18.2 & $<0.01$ & 0.06 & 0.58 & 4.16 & 32 \\
\hline A15 & $S$ & 30.9 & 5.58 & 440 & 1.71 & 25.4 & -4.34 & -28.3 & $<0.01$ & 0.27 & 0.24 & 3.22 & $>70$ \\
\hline A16 & $S$ & 30.2 & 6.27 & 152 & 0.05 & 1.1 & -4.3 & -24.9 & $<0.01$ & 0.08 & 0.28 & 0.05 & $>70$ \\
\hline B10 & $S$ & 31.2 & 4.7 & 38 & 3.83 & 0.3 & -5.21 & -29.8 & 0.08 & 0.44 & 0.21 & $\mathrm{~N} / \mathrm{A}$ & $>70$ \\
\hline B11 & $S$ & 30.8 & 5.14 & 51.5 & 0.24 & 0.4 & -4.65 & -23.4 & 0.09 & 0.12 & 0.52 & 1.62 & 37 \\
\hline B12 & $\mathrm{s}$ & 31.3 & 5.84 & 102 & $<0.05$ & 0.6 & -4.62 & -28.3 & 0.16 & 0.05 & 0.54 & 2.64 & 36 \\
\hline
\end{tabular}




\begin{tabular}{lccccccccccccc} 
M9 & B & 31.1 & 5.77 & 129.7 & 0.05 & 2.2 & -5.14 & -33.7 & 0.23 & 0.36 & 0.24 & 2.46 & $>70$ \\
M10 & B & 31.2 & 5.87 & 183.4 & 0.33 & 10.6 & -4.7 & -29.7 & 0.62 & 1.06 & 0.57 & 2.53 & 32 \\
M11 & B & 32.2 & 4.84 & 41.7 & 1.54 & 3.5 & -5.01 & -27.8 & 0.79 & 1.04 & 0.66 & 5.09 & 26 \\
M12 & B & 32.7 & 4.84 & 48.3 & 0.63 & 2.8 & -4.8 & -26.9 & 0.63 & 1.11 & 0.57 & 4.85 & 32 \\
M13 & B & 33 & 5.64 & 102.2 & 0.19 & 2.6 & -5.28 & -31.5 & 0.24 & 0.21 & 0.18 & 1.88 & 70 \\
M14 & B & 31.5 & 6.38 & 317 & 0.05 & 5.5 & -6.05 & -38.7 & 0.12 & 0.23 & 0.24 & 0.55 & 70 \\
M15 & B & 31.9 & 5.39 & 53.3 & 1.21 & 2.1 & -3.67 & -22.8 & 0.59 & 1.68 & 0.93 & 6.08 & 14 \\
M1 & S & 32 & 7.48 & 427 & 6.87 & 10.3 & -1.33 & -6 & 0.85 & 0.67 & 0.94 & 4.8 & 14 \\
M2 & S & 31.6 & 7.12 & 785 & 2.71 & 2.2 & -5.35 & -36.2 & 1.10 & 1.62 & 0.72 & 0.42 & 22 \\
M3 & S & 32.2 & 6.9 & 1051 & 1.36 & 17.9 & -4.63 & -29.7 & 0.53 & 1.53 & 4.37 & 3.33 & 70 \\
M4 & S & 33.5 & 7.06 & 856 & 2.72 & 10.7 & -3.62 & -21.9 & 0.43 & 0.81 & 0.91 & 4.68 & 15.5 \\
M5 & S & 32.4 & 6.93 & 1289 & 3.87 & 21.1 & -5.44 & -34.4 & 0.78 & 1.07 & 20.25 & 1.65 & 40 \\
M6 & S & 33.8 & 6.19 & 167 & 3.68 & 8.3 & -2.8 & -16.4 & 0.97 & 0.87 & 1.01 & 6.06 & 12 \\
M7 & S & 33.7 & 6.35 & 188 & 0.59 & 11.6 & -4.67 & -25.7 & 1.35 & 0.16 & 1.16 & 6.03 & 12 \\
M8 & S & 33.9 & 6.46 & 452 & 0.55 & 19.2 & -4.38 & -22.5 & 0.86 & 1.02 & 0.41 & 4.61 & 56 \\
\hline
\end{tabular}

$* \mathrm{~B}=$ Basement, $\mathrm{S}=$ Sedimentary, $* * \mathrm{MRT}=$ Mean residence time, ${ }^{\mathrm{a}}$ Small submersible motorised pump used to abstract water from borehole. MRTs calculated using $\mathrm{SF}_{6}$ data and CFC-12 data where suitable, N/A=data not available 